\title{
Az Önbevallásos Féltékenység Skála magyar változatának pszichometriai jellemzói
}

\author{
BUDINSZKI CINTIA* - HARGITAI RITA
}

Pázmány Péter Katolikus Egyetem, Pszichológiai Intézet,
Személyiség és Klinikai Pszichológia Tanszék, Budapest

(Beérkezett: 2019. szeptember 9.; elfogadva: 2020. március 1.)

\begin{abstract}
Elméleti háttér: A féltékenység mérésének számos egydimenziós és komplex mérőeszközét különböztethetjük meg egymástól. A méróeszközök egyike a diszpozícionális féltékenységet mérő 25 tételes Önbevallásos Féltékenység Skála. Cél: Az Önbevallásos Féltékenység Skála magyar nyelven nem érhető el, ezért a jelen tanulmány elsődleges célja e hiány pótlása, a kérdőív nagy elemszámú és széles életkori spektrumot átfogó mintán történő hazai adaptációja során szerzett tapasztalatok közreadása. Módszer: A keresztmetszeti, kérdőíves vizsgálaton alapuló kutatás során 1384 egészséges vizsgálati személy (átlagéletkor 27,3 [SD = 9,10] év) adatainak felhasználásával tártuk fel az Önbevallásos Féltékenység Skála faktorstruktúráját, annak illeszkedését, illetve teszteltük a mérési hatékonyság belső stabilitását. Eszközök: A tesztbattéria az Önbevallásos Féltékenység Skála mellett a validitás vizsgálatát szolgáló kérdőíveket az Epidemiológiai Kutatási Központ Depresszió Skáláját, a Spielberger-féle Vonásszorongás Kérdőívet, a Pszichológiai Jóllét Skálák kérdőívet, a WHO Jóllét Kérdőívének rövidített változatát, a Kapcsolati Elégedettség Skálát, valamint a Rosenberg Önértékelés Skálát tartalmazta. Eredmények: A feltáró faktoranalízis a kérdőív négy dimenzióját azonosította (a Párkapcsolati gyanakvás, a Reális párkapcsolati féltékenység, a Társas féltékenység és a Testvérféltékenység), amelyek a teljes variancia $62 \%$-át magyarázzák. A konfirmátoros faktoranalízis az eredeti, háromfaktoros modellel szemben a négydimenziós modell esetén jelzett megfelelő illeszkedést. A reliabilitásvizsgálat magas belső konzisztenciát mutatott. A nemi különbség, a részletes életkori csoportok elemzése és a párkapcsolati státusz vonatkozásában kapott adatok igazolják a féltékenység konstruktumvaliditását. Továbbá, a korábbi empirikus kutatásoknak megfelelően a féltékenység és az önértékelés vonatkozásában kapott gyenge negatív együttjárás $(r=-0,28 ; p<0,001)$ és a féltékenység depresszióval kapcsolatos gyenge pozitív $(r=0,30 ; p<0,001)$ és szorongással kapcsolatos mérsékelt pozitív korrelációja $(r=0,37$; $p<0,001)$ alátámasztja az Önbevallásos Féltékenység Skála konstruktum validitását. A Párkapcsolati gyanakvás és a Reális párkapcsolati féltékenység korrelációs együtthatói értékes információval járulnak hozzá a féltékenység megítélésének adaptív vs. maladaptív voltához. Összefoglalás: Az eredmények tükrében az Önbevallásos Féltékenység Skála a diszpozícionális féltékenység mértékének megbízható és érvényes mérőmódszere, amely további populációszintú és klinikai mintán történő kutatás számára nyújthat adekvát mérőeszközt.
\end{abstract}

Kulcsszavak: féltékenység, Önbevallásos Féltékenység Skála, reliabilitás, validitás, önértékelés, szorongás, depresszió

\footnotetext{
* Levelező szerző: Budinszki Cintia, Pázmány Péter Katolikus Egyetem, Pszichológiai Intézet, Személyiség és Klinikai Pszichológia Tanszék, 1088 Budapest, Mikszáth Kálmán tér 1. E-mail: cintia.budinszki@gmail.com
} 


\section{Bevezetés}

\subsection{A féltékenység konstruktuma}

A féltékenységet White és Mullen (1989) olyan gondolatok, érzelmek és cselekvések együtteseként határozzák meg, amelyek az önértékelés veszélyeztetettsége, illetve a szerelmi kapcsolat meglétének vagy minőségének fenyegetettsége esetén lépnek fel. Az észlelt fenyegetettség leggyakrabban a partner és egy másik fél közötti vonzalom percipiálásából eredeztethető (White \& Mullen, 1989; idézi: Hunyady, 1999).

A féltékenység jelenségét először Freud és Strachey (1922) magyarázták, az érzelem három szintjét különböztetve meg. 1 . A versengőt vagy normálisat, amelynek oka a gyászhoz hasonlóan a fontos másik elvesztésétől való félelem, illetve a nárcisztikus vágy az örömforrás visszaszerzésére. Annak ellenére, hogy Freud ezt a típust, mint normális féltékenységet írja le, annak megjelenése nem feltétlenül alapul a racionalitáson, és mélyen, az Ödipáliskonfliktusban gyökerezik. 2. A projiciált féltékenységet, amely a saját hütlenségre vonatkozó tudattalan vágyak másik félre való kivetítése következtében jön létre, valamint 3. a téveszmés féltékenységet, amelynek hátterében gyakran paranoid tartalmak, esetlegesen homoszexuális késztetések állnak. A harmadik szint önmagában sosem áll fenn, megjelenése az első két jellemzőhöz köthető. Freud és Strachey (1922) érvelése szerint a féltékenység az énvédő mechanizmusokhoz hasonló szerepet játszik: megvéd minket attól, hogy valami ártalmasabb tény tudatossá válhasson. Ezt a funkciót feltételezi Klein (1957) is: a féltékenység az irigységgel szembeni védekezésként jön létre, amit a szituációba bevont harmadik személyre vetítünk ki, ezáltal csökkentjük a búntudatot.

A féltékenység egyik első átfogó koncepciója Bringle (1991) tranzakcionalista modellje, amelyben három fő változó determinálja a féltékenység megjelenését, illetve annak mértékét: 1. az elkötelezödés, 2. a bizonytalanság és 3. a válaszkészség. Egy másik féllel való kapcsolat kialakítása - legyen szó első randevúról vagy akár házasságról - az elköteleződés bizonyos mértékével jár együtt. A másik fontos determináló tényező a bizonytalanság, amely a partner elköteleződésének személy általi kiértékeléséből származik. A harmadik meghatározó változó a válaszkészség: a féltékenység különböző érzelmi válaszokat generál (pl. félelem, düh, irigység), s a személyek eltérnek abban, hogy az egyes arousalfokozó szituációkban milyen mértékben mutatnak erőteljes érzelemmintát. A fenti tényezók együttjárása, vagyis a nagyobb elköteleződés, a fokozott bizonytalanság és a magasabb válaszkészség a féltékenység intenzitásának megnövekedésével és megjelenésének fokozott gyakoriságával jár együtt (Bringle, 1991). Bringle a modellt további elemekkel egészíti ki és amellett érvel, hogy az elköteleződést, a bi- 
zonytalanságot és a válaszkészséget három különböző forrás táplálja: a személy, a kapcsolat és a szituáció. A személlyel kapcsolatos változók, mint endogén tényezők lehetnek stabilak ( $\mathrm{pl}$. a személyiségvonások, a temperamentumjellemzők, a normák vagy az értékek); illetve lehetnek instabilak, mint amilyen például a személy aktuális hangulata vagy szexuális vágya. A kapcsolati tényezők közül stabilnak tekinthető a kapcsolati történet vagy az interakciós stílus, míg az átmeneti jellemzőkhöz például a legutóbbi nézeteltérések és az elsimított konfliktusok sorolódnak. A szituatív tényezők kontextuális jellemzőként (pl. a kapcsolatból származó gyerekek) vagy egyedi eseményként jelenhetnek meg (pl. a partner kapcsolaton kívüli aktuális viselkedése). A kapcsolati és szituatív tényezők együttesen az ún. exogén tényezőket alkotják. Bringle (1991) tranzakcionista modelljében a féltékenység tehát a különböző endogén és exogén változók közötti tranzakciók eredményeként jön létre, amelyek hatást gyakorolnak az elköteleződésre, a bizonytalanságra és a válaszkészségre.

Később a féltékenységet Buunk (1997) oly módon kategorizálta, hogy megkülönböztette a reaktív, a preventív és a szorongó féltékenységet. A reaktív féltékenység a reális érzelmi, illetve szexuális hútlenségre irányul. A preventív féltékenység a nevéból adódóan az esetleges hútlenség kivédésére szolgál, azáltal, hogy a személy próbálja megelőzni a partner harmadik féllel való kapcsolatát. Végül a szorongó féltékenység állandó aggodalmat, ruminációt jelent a partner és annak lojalitása felé. Ezen tipológia könnyen összeegyeztethető Bringle (1991) tranzakcionalista elméletével: szorongó féltékenység esetében az endogén tényezőkre, vagyis a személyhez kapcsolódó jellemzőkre helyeződik a hangsúly (pl. szorongásra, az alacsony önértékelésre). Ebben az esetben, a partner még nem is vonódott be egy harmadik féllel való kapcsolatba, azonban az egyén a legapróbb jelzéseket is arra használja, hogy megerősítse saját gyanakvását. Ugyanakkor a reaktív- és a preventív féltékenység során a lényeg az exogén elemeken van: előbbi esetében inkább a kapcsolaton s annak erodálódásán, míg az utóbbinál a szituáción. Preventív féltékenység esetén a személy úgy alakítja a kontextuális tényezőket, hogy csökkenjen a potenciális szexuális partnernek való kitettség.

Pfeiffer és Wong (1989) a féltékenységet - Bringle-hez hasonlóan - komplex jelenségként határozták meg, amely különböző gondolatok, érzelmek és viselkedéses elemek kölcsönhatásának következményeként jön létre. A szerzőpáros a hagyományos kognitív kiértékelés elméletekkel szemben, amelyek az érzelmet a környezeti ingerekre adott kognitív folyamat eredményének tekintették, egy parallel, interaktív modellt alkotott meg. Elméletük alapján az érzelem nemcsak a szeriális kognitív feldolgozás eredményeképpen, hanem mint az egyes ingerekre adott kondicionált válasz is megjelenhet. Emellett az aktuális fenyegető inger jelenléte sem elengedhetetlen a féltékenység kialakulásához, az gyökerezhet a személy aggodalmaiban, 
paranoid múködésmódjában is. A harmadik lényeges különbség a viselkedéses elemek szerepében rejlik. Míg a kognitív kiértékelés elmélet a cselekvéses elemeket, mint az érzelem megjelenésére adott coping mechanizmusokat kezeli, addig a multidimenzionális modell felhívja a figyelmet arra, hogy a kapcsolatban nemcsak protektív, hanem detektív (olyan viselkedéses elemek, amelyek a valós/képzelt rivális percipiálásából erednek, mint például kérdezősködés, a partner ellenőrzése) múködésmódok is megjelenhetnek, anélkül, hogy a szeriális feldolgozás végbemenne. A modell tehát egyszerre képes kezelni a patológiás és a normál féltékenységet. Az előbbi esetében a paranoid gyanakvás, a felfokozott érzelmek és a detektív viselkedésmódok dominálnak, amelyek elkerülhetetlenül negatív következményekkel járnak a párkapcsolatra, illetve annak alakulására nézve. Normál féltékenység esetében ezzel szemben megmarad az ingerhez kapcsolódó lineáris feldolgozás. A személy észleli a fenyegetést, erre mérsékelt érzelmi reakcióval válaszol, amelyet protektív viselkedésmintázat követ. Ebben az esetben az érzelem megjelenése pozitív hatást gyakorolhat a kapcsolatra, azonban túlzott intenzitás és/vagy gyakoriság esetén a patológiás féltékenységhez hasonló negatív kimenetelt hordozhat.

Fontos továbbá, hogy a féltékenységet elkülönítsük az irigységtől és a rivalizálástól. Míg a féltékenység esetében három fél kapcsolata kerül fókuszba, mivel egy kívülálló személy veszélyezteti a két emberből álló egység, az unió fennmaradását, addig a rivalizálás mindössze két személy ellentétéről szól, amit a birtoklási vágy hajt. Irigység esetén azonban nem beszélhetünk személyek közötti kölcsönhatásról, mivel ez a destruktív jellegú érzelem csak az egyénen belül jelenik meg és játszódik le, hátterében önértékeléscsökkenés áll (Haraszti, 1994). Annak ellenére, hogy a három érzelem egymástól jól elkülöníthető, a féltékenység megjelenéséhez potenciálisan irigység is társul, hiszen a rivális, aki a párkapcsolatunkat fenyegeti, felkeltette a számunkra fontos személy figyelmét, emellett összehasonlítási alapul is szolgál a számunkra. Ezáltal felfedezhetjük a rivális bizonyos irigylésre méltó tulajdonságait, amelyek belőlünk hiányoznak. Emellett az irigység szúkebb tartományú érzelem, kevésbé komplex jelenség, mint a féltékenység, ezzel is magyarázható az intenzitáskülönbség. Ugyanakkor az irigységet tekinthetjük a féltékenység egy faktorának is (Hunyady, 1999; Parrott \& Smith, 1993). Az irigységben és a féltékenységben közös, hogy mindkettó komplex, összetett jelenség, amely különböző emocionális elemekből áll össze. Ugyanakkor irigység esetén olyan affektív komponensek jelennek meg, mint a büntudat, a sóvárgás és a kisebbrendúségi érzés, míg féltékenység esetén a szorongás, az elutasítástól és a veszteségtől való félelem és a bizalmatlanság lesz meghatározó (Parrott \& Smith, 1993). 


\subsection{A féltékenység mérése}

Jelenleg több angol nyelvú kérdőíves eljárás is hozzáférhető, amelyek a féltékenység intenzitását, gyakoriságát, illetve annak típusait térképezik fel. Az egyik legrégebbi kérdőív az Interperszonális Féltékenység Skála (Interpersonal Jealousy Scale; Mathes \& Severa, 1981), amely egydimenziós mérőeszköz, s 28 tétellel tárja fel a vizsgálati személy esetében megjelenő féltékenységet és az arról alkotott hiedelmeket. A válaszadás kilencfokú Likert-típusú skálán történik annak függvényében, hogy a személy milyen mértékben ért egyet az adott állítással, illetve milyen szinten gondolja azt igaznak.

A kutatások többsége a Pfeiffer és Wong (1989) által kanadai mintán létrehozott Multidimenzionális Féltékenység Skálával (Multidimensional Jealousy Scale) mér, amely 24 tétel segítségével azonosítja a féltékenység kognitív, viselkedéses és emocionális elemeit. Az egyes dimenziók mindegyikéhez 8 állítás tartozik, amelyet a válaszadóknak az első két faktor esetében hétfokú Likert-típusú skálán az alapján kell értékelnie, hogy milyen gyakran áll fenn esetében az adott kognitív, illetve viselkedéses elem. A kognitív faktorba sorolható tételek a partner húségével kapcsolatos aggodalmakat és kételyeket fogalmazzák meg, míg a viselkedéses elemek a féltékenység által indukált cselekvések (pl. a partner zsebeinek átkutatása; napi aktivitásának ellenőrzése, kikérdezése) gyakoriságát jelzik. A harmadik, érzelmi komponens esetében a féltékenység érzelmének intenzitását mérjük: adott állítás kapcsán hétfokú Likert-típusú skálán kell döntenie a vizsgálati személynek, hogy az mennyire zaklatja fel. Az alacsony pontszámok minden dimenzió esetében a normál féltékenységet jelzik, míg a magas értékek és ezek együttjárásai a patológiás féltékenység indikátorai (Pfeiffer \& Wong, 1989).

A Buunk (1997) nevéhez fúződő Anticipált Szexuális Féltékenység Skála (Anticipated Sexual Jealousy Scale) szintén három faktorral rendelkezik, $\mathrm{s}$ a korábban már bemutatott három féltékenységtípust - a reaktívat, a preventívet és a szorongót - méri 5-5 tétel segítségével.

A közösségi média térhódításával a társas kapcsolatok jelentős változáson mentek keresztül. Ez eredményezte a Facebook Féltékenység Skála (Facebook Jealousy Scale; Muise, Christofides, \& Desmarais, 2009) megalkotását, amely a Facebook nevú közösségi portál speciális kontextusában térképezi fel a féltékenység mértékét. A mérőeszköz 27 tétel segítségével, hétfokú Likert-típusú skálán méri a féltékenységet. A kérdőív egydimenziós jellegú, amely a teljes variancia $47 \%$-át magyarázza.

A fenti mérőeszközökkel szemben az Önbevallásos Féltékenység Skála (Self-Report Jealosy Scale) a féltékenység diszpozícionális jellegét, annak 
vonásszintú aspektusát tárja fel. A féltékenységet mérő legkorábbi méróeszköz megalkotása Bringle, Roach, Andle és Evenbec (1979) nevéhez köthetó. A mérőeszközt 2013-ban Bringle revideálta, s egy nagyobb mintán végzett feltáró faktoranalízis eredményeként három faktorra bontotta. A Nem romantikus, a Mérsékelten romantikus és a Nagymértékben romantikus dimenziókra, amelyek a teljes variancia $50 \%$-át fedik le. A Nem romantikus faktor legjellemzőbb tétele a 21. „A testvéred/testvéreid több szeretetet és/vagy figyelmet kapnak a szüleidtól." Mérsékelten romantikus komponensbe sorolható a 4. „Egy összejövetelen a párod rajtad kívül mást is átkarol.” tétel, míg a Nagymértékben romantikus tengelyre a 22. „Rájössz, hogy a párodnak viszonya van egy munkatársával." állítás töltött a legerősebben. A kérdőív 25 tételt tartalmaz, amelyeket aszerint kell értékelni, hogy az adott szituáció a személyt elégedettséggel tölti el (0), enyhén felzaklatja (1), felzaklatja (2), nagyon felzaklatja (3), vagy extrém módon felzaklatja (4). A maximálisan elérhetó pontszám 100. A válaszokra adott értékek alapján a kitöltók 58 pontig alacsony, 59-82 pont között magas, 82 pont felett pedig extrém magas féltékenységgel jellemezhető csoportokba sorolhatók. A mérőeszköz kéthetes teszt-reteszt reliabilitása $(r=0,77)$ és belső konzisztenciája (Cronbach- $\alpha$ $=0,88-0,92)$ megfelelő, az általa mért dimenzió szignifikáns korrelációt mutat az alacsony önértékeléssel $(r=-0,36)$, az alacsony kontrollérzettel $(r=$ $0,30)$, a negatív életszemlélettel $(r=-0,25)$, a dogmatizmussal $(r=0,35)$, az élettel való elégedetlenséggel $(r=-0,46)$, valamint a szorongással $(r=0,36)$ (Bringle, 2013).

\subsection{A jelen vizsgálat célja}

Az Önbevallásos Féltékenység Skála magyar nyelven nem volt elérhető, ezért a jelen tanulmány elsődleges célja e hiány pótlása és a kérdőív nagy elemszámú mintán történő hazai adaptációja során szerzett tapasztalatok közreadása. Az adaptáció során ellenőrizzük a magyar nyelvú tételek alkalmazhatóságát. Feltáró és megerősítő faktorelemzéssel a faktorok szerkezetét vizsgáltuk, valamint teszteltük a mérési hatékonyság belső stabilitását is. Másodsorban, a konstruktumvaliditás vizsgálata során néhány - a téma szempontjából releváns korábbi empirikus kutatásokban már használt mérőeszköz segítségével ellenőriztük, hogy az alfaktorok értékei milyen kapcsolatot mutatnak a mentális egészség különböző indikátoraival és bizonyos mentális betegségeket előrejelző vonásokkal. A konstrumtumvaliditás szempontjából a párkapcsolati elégedettség, az életminőség és a pszichológiai jóllét, illetve a depresszió és a szorongásosság mértékének féltékenységgel mutatott kapcsolatrendszerét tárjuk fel. 


\section{Módszer}

\subsection{Minta és eljárás}

Keresztmetszeti, kérdőíves vizsgálatunkban a résztvevő személyek önkéntes jelentkezés alapján, ellenszolgáltatás nélkül vállalták a kutatásban való részvételt. Az adatgyújtés egyénileg zajlott, online felvétel formájában, kényelmi mintavétellel, a Facebook nevú közösségi portál különböző csoportjain keresztül. A vizsgálatba való bekerülés egyetlen kritériuma az életkor volt: abban csak a 18. életévüket betöltött személyek vehettek részt. A kutatást az Egyesített Pszichológiai Kutatásetikai Bizottság (EPKEB) hagyta jóvá (2018-122).

A kérdőívcsomagot összesen 1393 résztvevő töltette ki. A kitöltők közül 9 személy a vizsgálat elején az erre vonatkozó beleegyező nyilatkozat elolvasása után megtagadta a részvételt, illetve az adatai empirikus kutatási célokra történő felhasználását, így az ő válaszaik törlésre kerültek. A végleges minta így 1384 fóból áll. A részletes demográfiai adatokat az 1. táblázat szemlélteti.

1. táblázat. Demográfiai adatok

\begin{tabular}{|c|c|c|}
\hline \multicolumn{2}{|c|}{ Életkor [év; átlag (szórás)] } & $27,3(9,10)$ \\
\hline \multicolumn{2}{|c|}{ Életkori terjedelem (év) } & $18-67$ \\
\hline \multirow[t]{2}{*}{ Nem } & Férfi $n(\%)$ & $216(16 \%)$ \\
\hline & Nó $n(\%)$ & $1168(84 \%)$ \\
\hline \multirow[t]{3}{*}{ Iskolai végzettség } & Alapfokú $n(\%)$ & $79(6 \%)$ \\
\hline & Középfokú $n(\%)$ & $879(63 \%)$ \\
\hline & Felsőfokú $n(\%)$ & $426(31 \%)$ \\
\hline \multicolumn{2}{|c|}{ Oktatásban eltöltött évek száma [átlag (szórás)] } & $12,9(1,81)$ \\
\hline \multirow[t]{2}{*}{ Párkapcsolati státusz } & Egyedülálló $n(\%)$ & $1064(77 \%)$ \\
\hline & Kapcsolatban élő $n(\%)$ & $320(23 \%)$ \\
\hline
\end{tabular}

\subsection{Eszközök}

A vizsgálat során használt tesztbattéria egy demográfiai kérőívet, valamint hét önkitöltős becslőskálát tartalmazott.

Szociodemográfiai adatok. A demográfiai mérőeszköz kérdései az életkorra, a nemre, a családi állapotra, valamint az oktatásban eltöltött évek számára és a legmagasabb iskolai végzettségre irányultak. 
Önbevallásos Féltékenység Skála (Self-Report Jealousy Scale; SRJS; Bringle, 2013). A méróeszköz 25 állítást tartalmaz, amelyek a különböző szituációkban átélt féltékenység mértékét térképezik fel. A tételek egyike sem fordított. A válaszadás ötfokú Likert-típusú skálán történik, az alapján, hogy az adott szituáció a személyt elégedettséggel tölti el, enyhén felzaklatja, felzaklatja, nagyon felzaklatja, vagy extrém módon felzaklatja. A vizsgálat első lépéseként a szerző engedélyével a protokollnak megfelelóen kialakítottuk a kérdőív magyar nyelvú változatát. A kérdőív fordítását első lépésben két független fordító végezte, majd a szövegváltozatok közös egyeztetése és véglegesítése után egy harmadik fordító összevetette a magyar és az eredeti angol változatot. A kisebb jelentésbeli eltolódások korrigálását követően alakítottuk ki a jelen tanulmányban közölt szövegváltozatot. A kérdőívhez tartozó válaszlehetőségek azonban módosításra kerültek: a 0 ponthoz tartozó „elégedettséggel tölt el” választ a „egyáltalán nem zaklat fel” állításra cseréltük, mert véleményünk szerint ez pontosabban fejezi ki az „extrém módon felzaklat" válaszlehetőség ellenpólusát.

Kapcsolati Elégedettség Skála (RAS-H; Hendrick, Dicke, \& Hendrick, 1998; magyar változat: Martos, Sallay, Szabó, Lakatos, \& Tóth-Vajna, 2014). A skála a párkapcsolattal való elégedettséget méri hét plusz egy állítás segítségével. A nyolcadik tétel, mint kiegészítés szerepel a Martos és munkatársai (2014) által validált méróeszközben, nem része az eredeti skálának, így az jelen kutatás keretein belül nem került felvételre. A hét tétel közül 5 pozitív, míg 2 negatív megfogalmazású. A válaszadás ötfokú Likerttípusú skálán történik a kevéssé (1) és a nagyon (5) végpontok között. A magas pontszám magasabb kapcsolati elégedettséget implikál. A kérdőív magas belső konzisztenciával rendelkezik (férfiaknál a Cronbach- $\alpha=0,84$, nőknél a Cronbach- $\alpha=0,90)$, továbbá az időbeli stabilitása is magas $(r=0,90)$ (Martos és mtsai, 2014).

Rosenberg Önértékelés Skála (RSES-H; Rosenberg, 1965; magyar változat: Sallay, Martos, Földvári, Szabó, \& Ittzés, 2014). A globális önértékelést mérő kérdőív tíz tételt tartalmaz, öt pozitív és öt negatív irányú állítást, amelyekre négyfokú Likert-típusú skála segítségével adhat választ a kitöltő. A válaszlehetóségek végpontjai: egyáltalán nem értek egyet (1) és teljesen egyetértek (4). A magas pontszám magasabb önértékelést fejez ki. A belső konzisztencia vizsgálatánál a Cronbach- $\alpha$ értékek megfelelőnek bizonyultak (két külön időpontban 0,87, illetve 0,88). A mérőeszköz validitása is igazolást nyert (Sallay és mtsai, 2014).

WHO Jól-lét Kérdőív röviditett változata (WBI-5, Bech, Gudex, \& Johansen, 1996; magyar változat: Susánszky, Konkolÿ Thege, Stauder, \& Kopp, 2006). A mérőeszköz öt tétel segítségével méri a pszichológiai jóllétet. A válaszadás négyfokú Likert-típusú skálán történik az egyáltalán nem jellemző (0) és a teljesen jellemző (3) végpontok között. A skálán elért magasabb pont- 
szám pozitívabb, kedvezőbb pszichológiai állapotot jelez. A WHO Jól-lét Skálájának rövidített változata magas belső konzisztenciával rendelkezik, Cronbach- $\alpha$ értéke $(0,85)$ és teszt-reteszt reliabilitása $(r=0,65)$ is megfeleló (Susánszky és mtsai, 2006).

Pszichológiai Jóllét Skálák (PWB; Ryff \& Keyes, 1995; magyar változat: Oláh, 2012). A mérőeszköz 18 tételből áll, amelyek a pszichológiai jóllét 6 dimenzióját, az önelfogadást, a másokkal való pozitív kapcsolatot, az autonómiát, a környezeti hatékonyságot, az életcélt és a személyes növekedést mérik. A skálákon elért értékek összesített pontértéke a Pozitív Pszichológiai Múködés mutatója. A kitöltés során a vizsgálati személynek hatfokú Likert-típusú skálán, az egyáltalán nem értek egyet (1) és az erősen egyetértek (6) végpontok között kell jeleznie, hogy milyen mértékben ért egyet a felsorolt állításokkal. A magasabb pontszám a pszichológiai jóllét magasabb szintjét jelzi. A mérőeszköz dimenzióinak belső megbízhatósági mutatói gyenge, illetve mérsékelt értékeket vesznek fel (Cronbach- $\alpha=0,4-0,6)$, emiatt javasolt a kérdóív egydimenziós, Pozitív Pszichológiai Múködés mutatójának a használata (Cronbach- $\alpha=0,8)($ Oláh, 2012).

Epidemiológiai Kutatási Központ - Depresszió Skála (CES-D; Radloff, 1991; magyar változat: Perczel-Forintos és mtsai, 2018). A kérdőív elsősorban az általános populáció esetén megjelenő depresszió mértékét méri, de klinikai mintán is alkalmazható. A vizsgálatban résztvevő személyek 20 (egyenes és fordított irányú) tételen jelölik, hogy mennyire érezték önmagukra jellemzőnek az adott érzést vagy viselkedést azt elmúlt héten. A válaszadás négyfokú Likert-típusú skála segítségével történik a ritkán, vagy soha (kevesebb, mint 1 nap) (0) és a nagyon gyakran, vagy mindig (5-7 nap) (3) végpontok között. A magasabb pontszám a depresszív tünetek gyakoribb előfordulását mutatja. A mérőeszköz a depresszió kognitív, affektív, interperszonális és viselkedéses tüneteit egyaránt megbízhatóan méri (Cronbach- $\alpha \geq 0,75$ ) (Demetrovics, 2007).

Spielberger Vonásszorongás Skála (STAI-T; Vagg \& Spielberger, 1983; magyar változat: Sipos, Sipos, \& Spielberger, 1994). A mérőeszköz a szorongásra való hajlam feltárására szolgál. A kitöltés során a válaszadónak 20 tételt kell megválaszolnia, annak függvényében, hogy általában hogyan érzi magát. A válaszadás négyfokú Likert-skála segítségével történik az egyáltalán nem (1) és a nagyon/teljesen (4) végpontok között. A skálán elért magas pontszám a szorongásra való erősebb hajlamot jelzi. A mérőeszköz belső konzisztenciája magas (Cronbach- $\alpha=0,93$ ), érvényessége egybevág a nemzetközi eredményekkel (Sipos és mtsai, 1994).

Jelen vizsgálatban a mérőeszközök belső megbízhatósági mutatóit (Cronbach- $\alpha$ ), valamint a vizsgálati személyek egyes mérőeszközökön elért pontszámok átlagértékeit és szórását a 2. táblázatban foglaltuk össze. 
2. táblázat. A mérőeszközökön elért pontszámok átlaga és szórása, valamint az egyes méróeszközök belső megbízhatósága

\begin{tabular}{|c|c|c|}
\hline Méróeszköz & Átlag (szórás) & Cronbach- $\alpha$ \\
\hline Önbevallásos Féltékenység Skála & $48,88(17,85)$ & 0,93 \\
\hline Kapcsolati Elégedettség Skála & $28,35(5,98)$ & 0,91 \\
\hline Rosenberg Önértékelés Skála & $28,68(7,00)$ & 0,93 \\
\hline Pszichológiai Jól-lét Kérdőív (WBI 5) & $8,38(2,99)$ & 0,83 \\
\hline \multicolumn{3}{|l|}{ Pszichológiai Jóllét Skálák (PWB) } \\
\hline Autonómia & $12,25(1,55)$ & 0,52 \\
\hline Környezeti hatékonyság & $11,61(1,82)$ & 0,46 \\
\hline Önelfogadás & $7,27(3,06)$ & 0,69 \\
\hline Személyes növekedés & $13,35(2,01)$ & 0,63 \\
\hline Pozitíu kapcsolatok & $13,22(2,43)$ & 0,54 \\
\hline Életcél & $9,69(2,26)$ & 0,41 \\
\hline Összesitett mutatóként & $81,06(11,52)$ & 0,83 \\
\hline CES-D Depresszió skála & $18,84(12,23)$ & 0,93 \\
\hline Vonásszorongás Skála & $46,56(12,48)$ & 0,93 \\
\hline
\end{tabular}

\subsection{Alkalmazott statisztikai eljárások}

A skálák belső megbízhatóságának becslésére Cronbach-a-mutatót számítottunk. Az Önbevallásos Féltékenység Skála pszichometriai elemzésének első lépéseként feltáró modelleket alkalmaztunk. A későbbi keresztvalidálás céljából random módon két részre bontottuk a teljes mintát, igazítva azokat az eredeti életkori és nemi arányokhoz. Az így képzett alminták között nem volt szignifikáns eltérés az elemszámukban $(n 1=692$ fó; $n 2=692$ fó), az életkorban (Minta 1 : $M=27,01$ év; SD = 8,29 év; Minta $_{2} M=27,81$ év; SD = $9,48$ év; $t(1358,095)=-1,694 ; p=0,09)$ és a nemi arányukban $\left(\right.$ Minta $_{1} \mathrm{n}_{\mathrm{nŏ}}=$ $\left.577, \mathrm{n}_{\mathrm{ffi}}=115 ; \operatorname{Minta}_{2} \mathrm{n}_{\mathrm{nób}}=581 \mathrm{n}_{\mathrm{ffi}}=111 ; \chi^{2}(1)=0,085 ; p=0,771\right)$.

Az első almintán feltáró faktorelemzéssel (főkomponenselemzéssel; PCA) vizsgáltuk a kérdőív faktorszerkezetét és Cronbach- $a$-mutató számításával becsültük meg a faktorok belső konzisztenciáját. Következő lépésben a második almintán megerősítő faktoranalízis (CFA) segítségével validáltuk 
az exploratív faktorelemzés során azonosított modellt. A CFA során három modellt teszteltünk: 1. egy unidimenzionális modellt, ahol a tételek kizárólagosan egy globális féltékenység faktor alá rendeződnek; 2. egy háromfaktoros modellt, amely Bringle (2013) revideált modelljén alapul; valamint 3. a PCA során a jelen vizsgálat első almintáján azonosított modellt. A három hipotetikus modellt a megfigyelt adatokkal való egybeesésük mértékét jelzó illeszkedési mutatók mentén vetettük össze.

Ezt követóen feltártuk az Önbevallásos Féltékenység Skála konstruktum validitását, a RAS-H, az RSES-H, a WBI-5, a PWB, a CES-D és a STAI-T skálákkal való Pearson-féle korrelációi alapján.

Utolsó lépésként megvizsgáltuk, hogy az Önbevallásos Féltékenység Skála milyen módon függ össze az alapvetó szociodemográfiai jellemzókkel. Itt Pearson-féle korrelációs elemzést, valamint független mintás t-próbát alkalmaztunk, az utóbbi esetében hatásméret-mutatóként Cohen- $d$ számításával.

A közölt eredmények alapjául szolgáló elemzések az IBM SPSS Statistics v23 programmal készültek, a konfirmatív faktoranalízis pedig az IBM SPSS AMOS segítségével.

\section{Eredmények}

\subsection{Exploratív faktorelemzés}

Az Önbevallásos Féltékenység Skála faktorstruktúrájának feltárására fókomponens elemzést végeztünk a leggyakrabban használt Varimax (ortogonális) forgatással, amely biztosítja a létrejövő tengelyek függetlenségét. A mintában a parciális korrelációk kicsik $(\mathrm{KMO}=0,93)$ és a változók páronként nem függetlenek $\left(\chi^{2}(300)=10294,3 p<0,001\right)$, ami a tételek redukálhatóságát bizonyítja. Továbbá a változók között nincs kollinearitás (a korrelációs együtthatók értékei $r=0,02$ és $r=0,70$ között vannak), továbbá a determináns értéke alapján multikollinearitás sem áll fenn. A tételek közötti korrelációk tehát megfelelő erősségúek. A létrejövő főkomponensek közül a Kaiser-kritérium alapján az egynél nagyobb sajátértékkel rendelkezőket tartottuk meg, így négy faktor rajzolódott ki, amelyek az összvariancia 62,5\% -át magyarázzák. Az elemzésben csak azokat a tételeket jelenítettük meg, amelyek az adott tengelyre $b_{\mathrm{s}}=0,40$ érték felett töltenek, ez 16\%-os magyarázóerőt jelent. A faktorokat, a hozzájuk tartozó töltéseket, a sajátértékeket, a magyarázott varianciákat és a tengelyek belső megbízhatóságát a 3. táblázatban mutatjuk be részletesen. (A két faktorra is töltő tételeket kurzív módon jelöltük.) 


\section{3. táblázat. Az Önbevallásos Féltékenység Skála faktorszerkezete}

\begin{tabular}{|c|c|c|c|c|}
\hline \multirow[t]{2}{*}{ Tételek } & \multicolumn{4}{|c|}{ Faktorok } \\
\hline & I. & II. & III. & IV. \\
\hline $\begin{array}{l}\text { 11. Egy összejövetelen a párod olyan emberrel táncol, } \\
\text { akit nem ismersz. }\end{array}$ & 0,80 & & & \\
\hline $\begin{array}{l}\text { 7. Egy összejövetelen a párod megpuszil valakit, akit } \\
\text { nem ismersz. }\end{array}$ & 0,78 & & & \\
\hline $\begin{array}{l}\text { 5. Többször is rajtakapod a párod, hogy valaki mást } \\
\text { figyel. }\end{array}$ & 0,75 & & & \\
\hline $\begin{array}{l}\text { 14. Egy összejövetelen a párod többször is megpuszil } \\
\text { valakit, akit te nem ismersz. }\end{array}$ & 0,75 & & & \\
\hline $\begin{array}{l}\text { 6. A párod egyre több időt tölt olyan házon kívüli } \\
\text { tevékenységekkel, illetve hobbikkal, amikben te nem } \\
\text { veszel részt. }\end{array}$ & 0,75 & & & \\
\hline $\begin{array}{l}\text { 9. A párod több éjszaka nélküled megy el } \\
\text { szórakozóhelyre. }\end{array}$ & 0,74 & & & \\
\hline $\begin{array}{l}\text { 4. Egy összejövetelen a párod rajtad kívül mást is } \\
\text { átkarol. }\end{array}$ & 0,71 & & & \\
\hline $\begin{array}{l}\text { 10. A párodat elóléptetik, az új pozíciójával rengeteg } \\
\text { utazás, üzleti ebéd, összejövetel jár, melyek közül a } \\
\text { legtöbbre nem tarthatsz vele. }\end{array}$ & 0,69 & & & \\
\hline 13. Valaki flörtöl a pároddal. & 0,68 & & & \\
\hline $\begin{array}{l}\text { 17. A párod megemlíti, hogy egy másik személyt } \\
\text { nagyon vonzónak talál. }\end{array}$ & 0,68 & & & \\
\hline $\begin{array}{l}\text { 3. A párod hirtelen el szeretne menni egy összejövetelre, } \\
\text { amikor megtudja, hogy ott lesz egy korábbi szerelmi } \\
\text { partnere. }\end{array}$ & 0,62 & 0,43 & & \\
\hline $\begin{array}{l}\text { 18. Egy baráti összejövetelen a párod alig beszélget } \\
\text { veled, viszont a többiekkel élénk társalgást folytat. }\end{array}$ & 0,62 & & & \\
\hline $\begin{array}{l}\text { 2. A párod egyre több idejét tölti a munkahelyén egy } \\
\text { olyan munkatárs társaságában, akit szerinted partnered } \\
\text { szexuálisan vonzónak talál. }\end{array}$ & 0,62 & 0,50 & & \\
\hline 20. A párod valaki mással flörtöl. & 0,61 & 0,55 & & \\
\hline 15. A párod szexuális kapcsolatot létesít valaki mással. & & 0,86 & & \\
\hline $\begin{array}{l}\text { 22. Rájössz, hogy a párodnak viszonya van egy } \\
\text { munkatársával. }\end{array}$ & & 0,86 & & \\
\hline
\end{tabular}




\begin{tabular}{|c|c|c|c|c|}
\hline $\begin{array}{l}\text { 1. A párod kifejezi az igényét arra, hogy mindketten } \\
\text { alakítsatok ki másokkal is romantikus kapcsolatot. }\end{array}$ & & 0,73 & & \\
\hline $\begin{array}{l}\text { 24. A csoport, amihez tartozol, kihagy a terveiből, a } \\
\text { közös tevékenységeiből stb. }\end{array}$ & & & 0,76 & \\
\hline $\begin{array}{l}\text { 23. Az az ember, aki több évig az asszisztensed volt, } \\
\text { most úgy dönt, hogy másnál szeretne ugyanebben a } \\
\text { pozícióban dolgozni. }\end{array}$ & & & 0,72 & \\
\hline $\begin{array}{l}\text { 25. A legjobb barátod hirtelen egy másik személy iránt } \\
\text { érdeklődik, szívesen tölt együtt vele időt. }\end{array}$ & & & 0,71 & \\
\hline $\begin{array}{l}\text { 8. A fónököd, akivel régóta jó munkakapcsolatban állsz, } \\
\text { nagyobb érdeklődést tanúsít egy másik munkatársad } \\
\text { iránt. }\end{array}$ & & & 0,61 & \\
\hline $\begin{array}{l}\text { 12. Egy munkatársaddal keményen dolgoztatok egy } \\
\text { nagyon fontos projekten. A fónököd mégis csak neki } \\
\text { adott érte prémiumot. }\end{array}$ & & & 0,52 & \\
\hline $\begin{array}{l}\text { 21. A testvéred/testvéreid több szeretetet és/vagy } \\
\text { figyelmet kapnak a szüleidtől. }\end{array}$ & & & & 0,82 \\
\hline $\begin{array}{l}\text { 19. A nagyszüleid családi látogatást tesznek, és minden } \\
\text { figyelmüket a testvérednek/testvéreidnek szentelik. }\end{array}$ & & & & 0,81 \\
\hline $\begin{array}{l}\text { 16. A testvéred több szabadságot kap, mint te, például } \\
\text { tovább maradhat fent, vezetheti a családi autót, stb. }\end{array}$ & & & & 0,79 \\
\hline Sajátérték & 9,70 & 3,13 & 1,77 & 1,02 \\
\hline Megmagyarázott variancia & 28,99 & 13,61 & 10,89 & 8,95 \\
\hline Cronbach-a & 0,94 & 0,82 & 0,76 & 0,82 \\
\hline
\end{tabular}

Megjegyzés: első alminta, $n=692$; főkomponens elemzés, Varimax rotációval.

A fókomponens elemzés eredménye az eredeti háromfaktoros struktúrával szemben négy dimenziót jelez a sajátérték alapján. Az első faktorra 14 tétel tölt nagy mértékben. Ezek a tételek nem tartalmaznak konkrét bizonyítékot a partner hútlenségét tekintve, olyan szituációkat vázolnak, amelyek egy erre hajlamos személy számára felzaklatóak lehetnek. Olyan tételek tartoznak ide, mint például a 11. „Egy összejövetelen a párod olyan emberrel táncol, akit nem ismersz.” , 7. „Egy összejövetelen a párod megpuszil valakit, akit nem ismersz." 5. „Többször is rajtakapod a párod, hogy valaki mást figyel." Ezen dimenzió megfeleltethető Bringle (2013) Mérsékelten romantikus faktorának, azonban a pontosabb konceptualizáció érdekében Párkapcsolati gyanakvásnak neveztük el. 
A második alskálába 3 tétel sorolható, amelyek a már fennálló hútlenségre adott reakciókat mérik fel. Az alábbi állítások tartoznak ide. 15. „A párod szexuális kapcsolatot létesít valaki mással.”, 22. „Rájössz, hogy a párodnak viszonya van egy munkatársával." és az 1 . „A párod kifejezi az igényét arra, hogy mindketten alakítsatok ki másokkal is romantikus kapcsolatot.". Ezen dimenzió azonos Bringle (2013) Nagymértékben romantikus faktorával, azonban a pontosabb jelentéskonstrukció céljából Reális párkapcsolati féltékenységnek neveztük el.

A harmadik dimenzióra 5 tétel tölt jelentősen, amelyek baráti, illetve munkakapcsolatokban megjelenő féltékenységet indukáló eseményeket vázolnak. Példaként hozhatóak a 24. „A csoport, amihez tartozol, kihagy a terveiből, a közös tevékenységeiből stb.”, a 25. „A legjobb barátod hirtelen egy másik személy iránt érdeklődik, szívesen tölt együtt vele időt.” és a 23. „Az az ember, aki több évig az asszisztensed volt, most úgy dönt, hogy másnál szeretne ugyanebben a pozícióban dolgozni.". A tengelynek a társas támogatás analógiájára a Társas féltékenység nevet adtuk.

A negyedik tengelyhez 3 tétel tartozik. Az itt megjelenó állítások a testvérrel szemben megjelenő kisebbrendúségi érzésre reflektálnak. Ide sorolhatóak a 21. „A testvéred/testvéreid több szeretetet és/vagy figyelmet kapnak a szüleidtól.”, 19. „A nagyszüleid családi látogatást tesznek, és minden figyelmüket a testvérednek/ testvéreidnek szentelik." és a 16. „A testvéred több szabadságot kap, mint te, például tovább maradhat fent, vezetheti a családi autót stb." tételek. A dimenzió a Testvérféltékenység nevet kapta. Az általunk Társas féltékenységnek és Testvérféltékenységnek nevezett dimenziók együttesen alkotják Bringle (2013) kérdőívének Nem romantikus faktorát. Tehát a nem romantikus jellegú féltékenység finomítása, annak társas és testvérkapcsolatra való szétválása eredményezi a jelen mintán a négyfaktoros struktúra kirajzolódását az eredeti háromfaktoros helyett.

A 3. „A párod hirtelen el szeretne menni egy összejövetelre, amikor megtudja, hogy ott lesz egy korábbi szerelmi partnere.”, a 2. „A párod egyre több idejét tölti a munkahelyén egy olyan munkatárs társaságában, akit szerinted partnered szexuálisan vonzónak talál.” és a 20. „A párod valaki mással flörtöl." tétel a Párkapcsolati gyanakvás és a Reális párkapcsolati féltékenység dimenzióra egyaránt tölt. Ezen itemek esetében először ellenőriztük, hogy az adott tétel törlése növeli-e a hozzá tartozó skálák reliabilitását, ez azonban egyik esetben sem történt meg. Ezt követóen értelmeztük az állítások pontos tartalmát és ellenőriztük a faktortöltések erősségét. A tételeket ahhoz a skálához soroltuk, amelyre erősebben töltenek, illetve amelyik tartalmi köréhez szorosabban kapcsolódnak. Mivel a Reális párkapcsolati féltékenység kritériuma a reális, fennálló hútlenség percepciója, ami a felsorolt állítások egyikében sem jelenik meg, a fenti tételeket a Párkapcsolati gyanakvás dimenzióba soroltuk. 
Az alskálák reliabilitása kapcsán megállapítható, hogy a harmadik és a negyedik faktor alacsony tételszáma ellenére a kérdőív belső megbízhatósága mind a négy alskálát illetően megfelelő. Nem találtunk olyan tételt, amelynek ún. item-maradék korrelációja az átlagosan elfogadott 0,2-es értéknél (Rózsa, Nagybányai, \& Oláh, 2006) alacsonyabb volt, illetve a skálák Cronbach- $a$ értéke minden esetben elérte a kritikusnak tekinthető 0,6-os értéket (Cronbach- $a \geq 0,76$ ).

\subsection{Konfirmatív faktorelemzés}

Következő lépésben az exploratív eljárás során kapott modellt a minta második felén maximum-likelihood konfirmatív faktoranalízis (CFA) használatával keresztvalidáltuk. A CFA során összesen három modellt teszteltünk: 1. unidimenzionális modellt, 2. Bringle és munkatársai (2013) revideált háromfaktoros modelljét és 3. a PCA során általunk azonosított négyfaktoros modellt. A három hipotetikus modellt a megfigyelt adatokkal való egybeesésük mértékét jelző illeszkedési mutatók mentén vetettük össze.

Ahogy az a 4. táblázat illeszkedési mutatói alapján megállapítható, eredményeink nem támasztották alá az unidimenzionális szerkezetet. A háromfaktoros modell jobb illeszkedési mutatókkal rendelkezik, míg a négyfaktoros megoldás mutatja a legjobb illeszkedést.

4. táblázat. A modellek illeszkedési mutatói

\begin{tabular}{|l|c|c|c|c|c|}
\hline \multicolumn{1}{|c|}{ Modellek } & $\chi^{2}$ & df & RMSEA & CFI & TLI \\
\hline Egydimenziós modell & 3560,33 & 275 & 0,13 & 0,66 & 0,63 \\
\hline $\begin{array}{l}\text { Háromfaktoros modell } \\
\text { (Bringle és mtsai, 2013) }\end{array}$ & 1435,48 & 265 & 0,09 & 0,88 & 0,86 \\
\hline Négyfaktoros modell (jelen vizsgálat) & 1323,09 & 269 & 0,08 & 0,89 & 0,88 \\
\hline
\end{tabular}

Megjegyzés: második alminta, $n=692 ;$ RMSEA = a reziduumok átlagos négyzetgyöke; CFI = komparatív illeszkedési mutató, TLI = Tucker-Lewis illeszkedési mutató.

Noha a négyfaktoros modell mutatja a legjobb illeszkedést, az elemzés CFI és TLI értéke elmarad az elvárt > 0,9-es értéktől. A modifikációs indexek vizsgálata azt az eredményt hozta, hogy amennyiben olyan alternatív modellt állítunk fel, amelyben megengedjük egyes tételpárok hibatagjai között a korrelációt, akkor a négyfaktoros mérési modell adatokra való illeszkedése jelentősen javul (a $\chi^{2}$ különbsége: 201,8; a szabadságfok különbsége: $4 ; p<0,001)$ és megfelelő illeszkedést mutat. E faktoriális struktúra esetében 
az illeszkedési mutatók a következőképpen alakulnak: $\left(\chi^{2}(265)=1121,29 ; p\right.$ $<0,001$; CMIN/DF = 4,231; CFI = 0,912; TLI = 0,90; RMSEA = 0,068; RMSEA $\left.\mathrm{CI}_{90}=0,064-0,073\right)$. E tételpárok közötti kapcsolat jól értelmezhető: a Párkapcsolati gyanakvás 11. és 13. tétele korrelál $(r=0,57 ; p<0,001)$. Ugyanebben a faktorban a 9. és a 10. tétel $(r=0,55 ; p<0,001)$, illetve a 2 . és a 4 . tétel együttjárást mutat $(r=0,56 ; p<0,001)$. A Társas féltékenység faktoron belül a 8 . és a 12. tétel korrelál $(r=0,29 ; p<0,001)$, mindkettó a főnök-beosztott munkakapcsolatban megjelenő féltékenységre reflektál.

\subsection{Konstruktum validitás}

A konstruktum validitás ellenőrzéséhez Pearson-féle korrelációs elemzéssel megvizsgáltuk az Önbeszámolós Féltékenység Skála pontszámai és a további felvett kérdőívek pontértékei közötti kapcsolatot. A féltékenység szignifikáns, gyenge, negatív irányú kapcsolatot mutat az önértékeléssel $(r=-0,28$; $p<0,001)$, továbbá szignifikáns, gyenge, pozitív irányú kapcsolatban áll a depresszív tünetekkel $(r=0,30 ; p<0,001)$ és közepes mértékú, pozitív irányú összefüggést mutat a vonásszorongással $(r=0,37 ; p<0,001)$. A mentális egészséggel összefüggésbe hozható pszichológiai jólléttel szignifikáns, gyenge, negatív irányú kapcsolatot tártunk fel $(r=-0,25 ; p<0,001)$. Meglepő módon a kapcsolati elégedettséggel való együttjárás bár szignifikánsnak, ám statisztikailag elhanyagolható erősségúnek bizonyult $(r=-0,08 ; p=005)$.

Az alskálák közül a Párkapcsolati gyanakvás és a vonásszorongás mutatja a legerősebb - közepes mértékú - kapcsolatot. Az alskálák tekintetében az alábbi mintázat bontakozik ki: a Párkapcsolati gyanakvás, a Társas féltékenység és a Testvérféltékenység szignifikáns, de gyenge kapcsolatot mutat a depreszszióval, a szorongással és a pszichológiai jóllét mutatóival. Ezzel szemben a Reális párkapcsolati féltékenység a fenti változókkal statisztikailag igen gyenge, több ízben elhanyagolható erósségú összefüggést jelez $(r \leq|0,15| ; p<$ 0,01). A korrelációs együtthatókat az 5 . táblázat szemlélteti részletesen. 


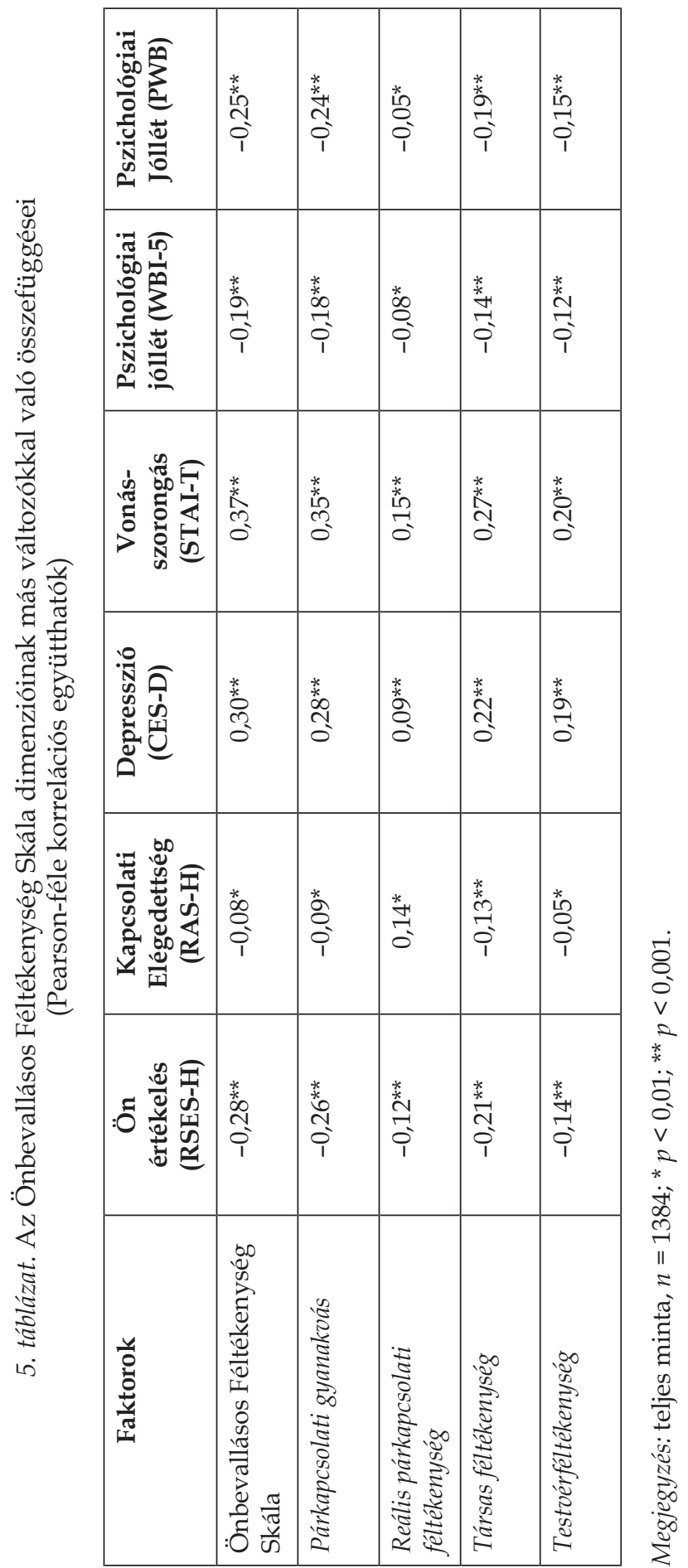




\subsection{Szociodemográfiai változókkal való összefüggés}

A kérdőív konstruktum validitásának további vizsgálatához az Önbevallásos Féltékenység Skálán elért pontszámok demográfiai változókkal való kapcsolatát vizsgáltuk Pearson-féle korrelációs elemzéssel. Az átélt féltékenység mértéke szignifikáns, gyenge, negatív irányú kapcsolatot mutat az életkorral $(r=-0,22 ; p<0,001)$ és az oktatásban eltöltött évek számával $(r=$ $-0,12 ; p<0,001)$. A méróeszköz egyes alskáláival való összefüggéseket részletesen a 6. táblázat foglalja össze. Látható, hogy az életkor valamennyi alskálával szignifikánsan korrelál, a Párkapcsolati gyanakvással és a Reális párkapcsolati féltékenységgel mutatva a legszorosabb kapcsolatot. Ezzel szemben az iskolázottság egyedül a Párkapcsolati gyanakvással korrelál szignifikánsan.

6. táblázat. Az Önbevallásos Féltékenység Skála faktorainak demográfiai változókkal való összefüggése (Pearson-féle korrelációs együtthatók)

\begin{tabular}{|l|c|c|}
\hline \multicolumn{1}{|c|}{ Skálák } & Életkor & $\begin{array}{c}\text { Iskolázottság } \\
\text { (az oktatásban eltöltött } \\
\text { évek száma) }\end{array}$ \\
\hline $\begin{array}{l}\text { Önbevallásos Féltékenység Skála } \\
\text { (összpontszám) }\end{array}$ & $-0,22^{* *}$ & $-0,12^{* *}$ \\
\hline Párkapcsolati gyanakvás alskála & $-0,20^{* *}$ & $-0,14^{*}$ \\
\hline Reális párkapcsolati féltékenység alskála & $-0,26^{* *}$ & $-0,01$ \\
\hline Társas féltékenység alskála & $-0,09^{*}$ & $-0,03$ \\
\hline Testvérféltékenység alskála & $-0,08^{*}$ & $-0,02$ \\
\hline
\end{tabular}

Megjegyzés: * $p<0,01 ;{ }^{* *} p<0,001$.

Az összpontszám tükrében végzett nemi összehasonlító elemzés statisztikailag szignifikáns különbséget jelez (1. ábra): a nők magasabb pontszámot értek el az Önbevallásos Féltékenység Skálán, mint a férfiak $\left(\mathrm{M}_{\mathrm{f}}=40,19\right.$; $\left.\mathrm{SD}=18,86 ; \mathrm{M}_{\mathrm{n}}=50,49 ; \mathrm{SD}=17,19 ; t(1382)=-7,96 p<0,001\right)$; a hatásméret (Cohen, 1988) közepesnek bizonyult: Cohen- $d=0,59$. Ez a különbség az alskálák szintjén is megmutatkozik. Párkapcsolati gyanakvás: $\mathrm{M}_{\mathrm{f}}=21,71 ; \mathrm{SD}=$ 13,$40 ; \mathrm{M}_{\mathrm{n}}=27,57 ; \mathrm{SD}=13,13 ; t(1382)=-6,01 ; p<0,001$; Cohen- $d=0,44$; Reális párkapcsolati féltékenység: $\mathrm{M}_{\mathrm{f}}=9,27 ; \mathrm{SD}=2,98 ; \mathrm{M}_{\mathrm{n}}=10,61 ; \mathrm{SD}=2,22$; $t(261,03)=-6,25 ; p<0,001 ;$ Cohen- $d=0,57$; Társas féltékenység: $\mathrm{M}_{\mathrm{f}}=6,50 ; \mathrm{SD}$ $=3,64 ; \mathrm{M}_{\mathrm{n}}=8,33 ; \mathrm{SD}=3,61 ; t(1382)=-6,80 ; p<0,001$; Cohen- $d=0,51$; Test vérféltékenység: $\mathrm{M}_{\mathrm{f}}=2,71 ; \mathrm{SD}=2,84 ; \mathrm{M}_{\mathrm{n}}=3,99 ; \mathrm{SD}=2,90 ; t(1382)=-5,97 ; p<$ 0,001 ; Cohen- $d=0,44$. 


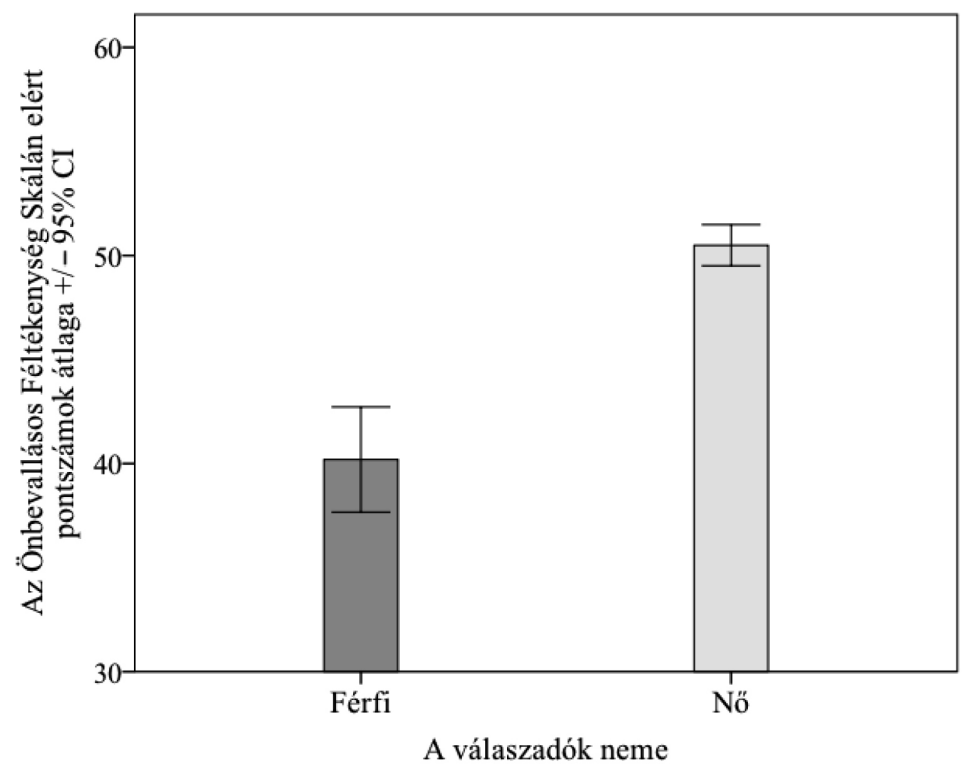

1. ábra. Az Önbevallásos Féltékenység Skálán elért összpontszámok tekintetében mutatkozó nemi különbségek

Továbbá, a féltékenység tekintetében szignifikáns különbség mutatkozik az aktuálisan párkapcsolatban élők és az egyedülállók között (2. ábra) $\left(\mathrm{M}_{\mathrm{p}}=\right.$ 49,$\left.86 ; \mathrm{SD}=17,91 ; \mathrm{M}_{\mathrm{e}}=45,65 ; \mathrm{SD}=17,30 ; t(1382)=-3,71 ; p<0,001\right)$, ugyanakkor a hatásméret gyenge (Cohen- $d=0,22)$. Ez a különbség a Testvérféltékenység dimenziót leszámítva az alskálák esetén is megmutatkozik. Párkapcsolati gyanakvás: $\mathrm{M}_{\mathrm{p}}=27,67 ; \mathrm{SD}=13,61 ; \mathrm{M}_{\mathrm{e}}=23,31 ; \mathrm{SD}=11,82 ; t(595,99)=$ $-5,57 ; p<0,001$; Cohen- $d=0,33$; Reális párkapcsolati féltékenység: $\mathrm{M}_{\mathrm{p}}=10,53$; $\mathrm{SD}=2,36 ; \mathrm{M}_{\mathrm{e}}=9,95 ; \mathrm{SD}=2,52 ; t(499,58)=-3,66 ; p<0,001 ;$ Cohen $-d=0,24$; Társas féltékenység: $\mathrm{M}_{\mathrm{p}}=7,93 ; \mathrm{SD}=3,60 ; \mathrm{M}_{\mathrm{e}}=8,42 ; \mathrm{SD}=3,89 ; t(1382)=2,10 ; p$ $=0,04 ;$ Cohen- $d=0,13$; Testvérféltékenység: $\mathrm{M}_{\mathrm{p}}=3,73 ; \mathrm{SD}=2,87 ; \mathrm{M}_{\mathrm{e}}=3,97 ; \mathrm{SD}$ $=3,10 ; t(494,83)=1,20 ; p=0,23$; Cohen- $d=0,08$.

Jelen mintát tekintve tehát a nők, illetve az aktuálisan párkapcsolatban élók összességében magasabb féltékenység értéket mutatnak, mint a férfiak, illetve az egyedülállók. 


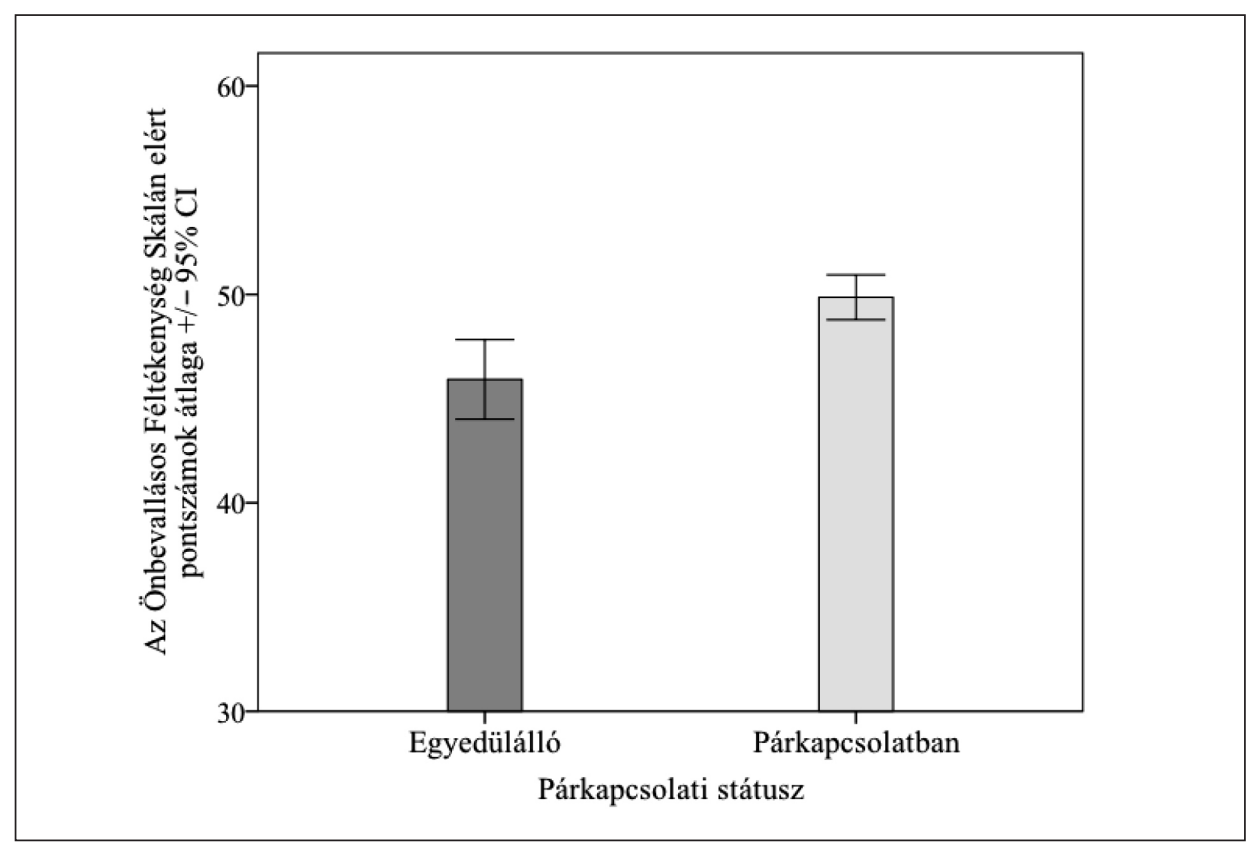

2. ábra. A párkapcsolati státusz és az Önbevallásos Féltékenység Skálán elért összpontszámok összefüggése

A következő lépésben a nemi különbségek és az életkori differenciálódás átfogóbb vizsgálatához a férfiakat és a nőket reprodukciós szempontok alapján életkori csoportokba soroltuk: 18-25 év, 26-45 év, 46-70 év közöttiekre. Majd az így létrehozott csoportokat kétszempontos független mintás ANOVA segítségével hasonlítottuk össze. Az analízís során a nem főhatása $(\mathrm{F}(1,1377)=33,61 ; p<0,001)$ és az életkor főhatása $(\mathrm{F}(2,1377)=17,17 ; p<$ 0,001) egyaránt szignifikánsnak bizonyult, azonban a két változó közötti interakció nem volt szignifikáns $(\mathrm{F}(2,1377)=0,18 ; p=0,840)$. Eredményeink alapján a nők esetében a Tukey post hoc vizsgálat alapján a 18-25 éves korosztály ( $n=688, \mathrm{M}_{18-25}=52,60$; SD = 16,43) féltékenységének mértéke szignifikánsan különbözik mind a 26-45 éves $\left(n=415, \mathrm{M}_{26-45}=48,60 ; \mathrm{SD}=17,54\right.$; $p<0,001)$, mind a 46-70 éves korcsoporttól $\left(n=65, \mathrm{M}_{46-70}=40,45\right.$; SD = $17,19 ; p<0,001)$. A 26-45 éves és a 46-70 éves korosztály között szintén szignifikáns különbség mutatkozik $(p=0,001)$. Megállapítható tehát, hogy a nők féltékenységének mértéke az életkor előrehaladtával fokozatosan csökken.

A férfiak esetében szintén Tukey post hoc utótesztet végezve azonban nem találtunk szignifikáns különbséget a 18-25 éves $\left(n=113, \mathrm{M}_{18-25}=43,50\right.$; $\mathrm{SD}=18,93)$, illetve a $26-45$ éves $\left(n=85, \mathrm{M}_{26-45}=38,12 ; \mathrm{SD}=18,72 ; p=0,108\right)$ 
továbbá a 26-45 éves $\left(n=85, \mathrm{M}_{26-45}=38,12\right.$; $\left.\mathrm{SD}=18,72\right)$ és a $46-70$ éves $(n=$ $\left.18, \mathrm{M}_{46-70}=29,28 ; \mathrm{SD}=13,59 ; p=0,158\right)$ korcsoportok között. Az egyetlen szignifikáns különbség a 18-25 és a 46-70 éves korosztály között mutatkozott $(p=0,008)$. A feltárt összefüggéseket a 3. ábrán szemléltetjük.

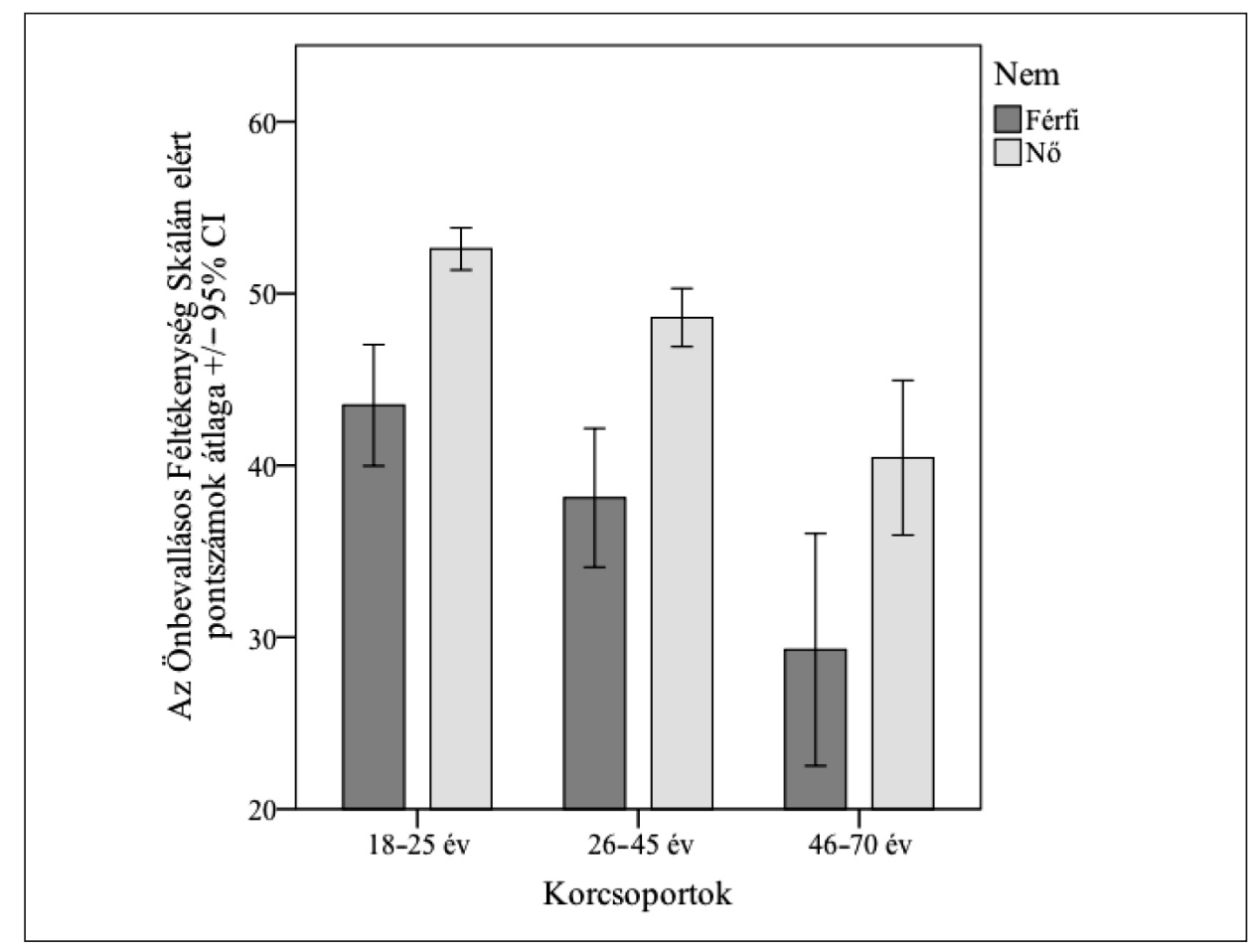

3. ábra. A különböző korcsoportok közötti különbségek az Önbevallásos Féltékenység Skálán elért összpontszámok tükrében

\section{Megbeszélés}

Noha számos angol nyelvú kérdőív létezik a féltékenység operacionalizálására, tudomásunk szerint jelen tanulmány az első, amely a féltékenység egyik mérőeszközének hazai adaptációját tárgyalja. Az Önbevallásos Féltékenység Skála (Self-Report Jealousy Scale; Bringle, 2013) korábban nem volt elérhető magyar nyelven, ezért a jelen tanulmány elsődleges célja e hiány pótlása, a kérdőív nagy elemszámú mintán történő hazai adaptációja során szerzett tapasztalatok közreadása.

Az Önbevallásos Féltékenység Skála magyar nyelvú változatának elkészítése után első lépésben ellenőriztük a kérdőív faktorstruktúráját. A főkomponens elemzés alapján az eredeti kérdőív háromfaktoros stuktúrájával 
szemben egy négyfaktoros elrendezés rajzolódott ki, amelyek együttesen az összvariancia 62,5\%-át magyarázzák. A Párkapcsolati gyanakvás faktorba öszszesen 14 item tartozik. Az ide sorolható tételek olyan szituációkat írnak le, amelyek nem implikálnak valódi hútlenséget, mindössze egy harmadik féllel való interakcióra utalnak, következésképpen a partner húségének megkérdőjelezéséből adódó aggodalmat mérik. A Reális párkapcsolati féltékenység dimenzió 3 tételt tartalmaz, az ide sorolódó tételek valódi - érzelmi vagy szexuális - hútlenséget tükrőző szituációkat írnak le. Bringle (2013) harmadik, Nem romantikus féltékenységet leíró eredeti faktorának tételei jelen kutatásban két alfaktorba sorolódtak: a Társas féltékenység dimenzió 5 itemet foglal magába. A komponensbe tartozó tételek olyan eseményeket foglalnak magukba, amelyek során a baráti, valamint munkakapcsolatok fennállását, illetve azok minőségét egy harmadik fél veszélyezteti. Az eredeti, Nem romantikus féltékenység másik faktorát jelen mintán a Testvérféltékenység dimenzió alkotja, amelyhez 3 tételt soroltunk, ezek a testvérrel szembeni kisebbrendûségi érzésre reflektálnak. A személy családon belüli kapcsolati hálóban elfoglalt helye, illetve annak megváltozása indukálja az érzelem megjelenését. A három- és a négyfaktoros struktúra konfirmátoros faktoranalízissel történő összehasonlítása alapján a négyfaktoros, tehát a Nem romantikus kapcsolatokat érzékenyebben feltáró, azt Társas-és Testvérféltékenység faktorra szétbontó struktúrája nyert alátámasztást. Az egyes tételpárok hibatagjai közötti korreláció megengedésével a modell illeszkedése megfelelőnek bizonyult.

Az Önbevallásos Féltékenység Skála konstruktum validitásának ellenőrzése során gyenge, negatív irányú kapcsolatot tárunk fel az önértékeléssel, valamint a féltékenység vonása gyenge, pozitív irányú kapcsolatban áll a depresszív tünetek meglétével és közepes mértékú összefüggést mutat a vonásszorongással. Ezen eredmények messzemenőkig megerősítik a nemzetközi kutatási eredményeket, a kapcsolat irányát és annak erejét tekintve egyaránt (ld. pl. Costa, Sophia, Sanches, Tavares, \& Zilberman, 2015; Lennarz, Lichtwarck-Aschoff, Finkenauer, \& Garnic, 2017; Lima \& mtsai, 2017; Rőmer \& Fekete, 2014). Az Önbevallásos Féltékenység Skála a féltékenységet deklaráltan diszpozíciónak tekinti, tehát az önértékelés, a szorongás, mint vonás és a depresszió vonatkozásában kapott eredmények ezen konceptulizációnak teljes mértékben megfelelők. Mindez oly módon magyarázható, hogy az alacsony önértékelésú, szorongó személyek önmagukat nem tartják megfelelő partnernek, következésképpen a potenciális rivális által könnyebben érzik magukat fenyegetve (Peretti \& Pedowski, 1997). A féltékenység depresszióval és a szorongással mutatkozó összefüggése pedig egybevág Stravogiannis és munkatársai (2018) friss kutatási eredményével, amely szerint a patológiás mértékú féltékenységgel jellemezhető sze- 
mélyek társuló pszichopatológiai zavarként 47\%-ban major depressziót és 18\%-ban szorongásos kórképeket (pánikzavart, agorafóbiát, szociális fóbiát, kényszerbetegséget) mutatnak.

A konstruktum validitás szempontjából kutatásunk egyik legrobusztusabb eredménye a féltékenység tekintetében kapott nemi különbség: a nők magasabb féltékenységgel jellemezhetők, mint a férfiak. Ezen eredmények egybevágnak a nemzetközi adatokkal (ld. pl. Elphinston, Feeney, \& Noller, 2011; Mathes \& Severa, 1981; McAndrew \& Shah, 2013). Jelen kutatás eredményei szerint a féltékenység fordított irányú, szignifikáns, de gyenge kapcsolatot mutat az életkorral. Ezen eredményt Bendixen, Kennair és Buss (2015), illetve Tagler és Gentry (2011) eredményei nem erősítik meg. Kisebb, de reprezentatív amerikai mintán történő adatfelvétel sem igazolta az életkorral való kapcsolatot (Green \& Sabini, 2006). A féltékenység életkori és nemi összefüggésére vonatkozó összefüggés pontosabb feltárásához a férfiakat és a nőket reprodukciós szempontok alapján életkori csoportokba soroltuk: 18-25 év, 26-45 év, 46-70 év közöttiekre. Az életkori csoportok öszszehasonlítása során megállapítottuk, hogy a nők féltékenységének mértéke az életkor előrehaladtával fokozatosan csökken, míg a férfiaknál a 18-25 és a 46-70 év közötti csoportnál mutatkozott szignifikáns különbség. Tehát, ahogyan az az evolúciós hipotézis (Buss, Larsen, Westen, \& Semmelroth, 1992) értelmében várható volt, a férfiak esetében a féltékenység tekintetében a legnagyobb különbség azoknál az életkori csoportoknál rajzolódott ki, amelyeknél a nők reprodukciós értéke a legmagasabb, illetve ahol a legalacsonyabb. Más szavakkal, a férfiak esetében a féltékenység intenzitásának életkor előrehaladtával való csökkenése a nők csökkenő reprodukciós kapacitásának tükrében magyarázható. Továbbá, a féltékenység konceptualizációjának megfelelóen megállapítottuk, hogy az aktuálisan párkapcsolatban élők magasabb féltékenység értékkel jellemezhetők, mint az egyedülálló vizsgálati személyek. Mindez egybevág Voracek (2001) kutatási eredményével, aki regressziós modellben vizsgálata a féltékenység prediktorait, $\mathrm{s}$ egyéb változók kontrollálása mellett a párkapcsolati státusz erős bejósló tényezőnek bizonyult.

Kutatásunk újszerúségét az adja, hogy a pszichopatológiát előrejelző személyiségvonások mellett a mentális egészséggel összefüggésbe hozható tényezőkkel is vizsgáltuk a féltékenység kapcsolatát. A pszichológiai jóllét mutatóival végzett korrelációs vizsgálat a féltékenységgel szignifikáns, de gyenge, negatív irányú kapcsolatot tárt fel. A negatív korreláció jól értelmezhető a jóllét ernyőfogalmának társas-kapcsolati dimenziója által közvetlenül: a féltékenység vonásával jellemezhető személyek a körülöttük lévő embereket kevésbé ítélik támaszt nyújtónak, gondoskodónak. Továbbá elképzelhető, hogy a féltékenység és a jóllét közötti negatív kapcsolatot közve- 
tetten - a szorongás és az önértékelés mediálásával - is magyarázhatjuk, ebben az esetben vélhetóen a szorongás a jóllét elemei közül a pozitív érzelmekre és a szomatikus múködésre fejtheti ki a hatását, míg az önértékelés az autonómián, a személyes növekedésen és az életcélok megvalósításán keresztül juthat érvényre. Adekvát nemzetközi empirikus kutatások hiányában a jelen vizsgálat során feltárt kapcsolat erejét nem tudjuk más kutatások tükrében megítélni.

A párkapcsolati elégedettség vonatkozásában gyenge, szinte elhanyagolható kapcsolat mutatkozott a korrelációs vizsgálat során a féltékenységgel, miközben a párkapcsolati státusz szignifikáns, gyenge hatásméretet jelzett. Ennek alapján úgy túnik, hogy a kapcsolat minőségével szemben inkább annak megléte vagy hiánya (párkapcsolatban él vagy egyedülálló) a mérvadó a diszpozícionális féltékenység tekintetében. E látszólagos ellentmondás feloldható Bringle (1991) tranzakcionalista modelljében, ahol a kapcsolat minőségével szemben inkább a kapcsolat iránti elköteleződés tekinthető a féltékenység fontos prediktor változójának. Ennek alapján a párkapcsolatok minőségi jellemzői, illetve az elkötelezés mértéke mentén további empirikus kutatások indokoltak.

Az Önbevallásos Féltékenység Skála faktorainak korrelációs együtthatói érdekes összefüggést jeleznek a féltékenység adaptív-maladaptív jellege mentén: a faktorok közül a Párkapcsolati gyanakvás mutatja a legerősebb öszszefüggést a szorongás és a depresszió magas, illetve az önértékelés és a pszichológiai jóllét alacsony voltával. Ezzel összemérhető a Társas féltékenység és a Testvérféltékenység depresszió, szorongás és jóllét vonatkozásában kapott eredménye. Ily módon ezeken a faktoron elért magas érték jelezheti a patológiás féltékenységre való hajlamot, illetve annak fennállását. Ezzel szemben a Reális párkapcsolati féltékenység minden esetben igen gyenge, statisztikailag akár elhanyagolható erősségú lineáris összefüggést mutatott a vizsgált változókkal. Ennek tükrében ezt a dimenziót tekinthetjük úgy, mint a féltékenység adaptív formáját, amely a partner hútlenségének megalapozottsága - mint fennálló exogén tényezó - miatt nem mutat kapcsolatot az endogén, vagyis személyi változókkal (ld. szorongás, depresszió, önértékelés). Ezen összefüggés nemcsak Bringle (1991) tranzakcionalista modellje mentén értelmezhetó, de párhuzamba állítható Pfeiffer és Wong (1989) elméletével is: a kutatók a patológiás féltékenységet a személyiség paranoid gyanakvásában, fokozott szorongásában gyökerező tényezőként kezelik, míg a normális féltékenység megjelenését a vonásoktól sokkal inkább független, környezeti tényezőkön alapuló érzelemként tartják számon.

Az eredmények értelmezésekor fontos figyelembe venni a vizsgálat módszertani korlátait, elsőként az adatgyújtésből származót. Ezek közül legfontosabb a nemi arány egyenlőtlensége: a kutatásban sokkal több nő, mint férfi vett részt $(84 \%)$. A nemi hovatartozást fontos változóként kezel- 
tük, következésképpen nehéz megbízható általánosítást tenni a teljes populáció vonatkozásában, miközben a mintát elsődlegesen nők alkották. További lényegi korlát, hogy az adatgyứjtés online felületen, kényelmi mintavételi eljárás segítségével történt, amely korlátozza az eredmények általánosíthatóságát. Mi több, Sagarin és munkatársai (2012) szerint az online felületen történő számítógépes válaszadás csökkenti a kimutatott hatásnagyságokat is. A szignifikáns, de gyenge korrelációs együtthatók magyarázhatók azzal is, hogy a féltékenység komplex jelenségével szemben az Önbevallásos Féltékenység Skála csupán a személyi változóra, a féltékenységre, mint diszpozicionális jellemzőre (trait) fókuszál. Nem kezeli a partner elköteleződésének személy általi kiértékeléséből származó kognitív tényezőket és a személy - viselkedéses vagy érzelmi - válaszkészségét sem, miközben ismert, hogy a diszpozícionális típusú jellemzőkön túl rendkívül fontos tudni, hogy bizonyos arousalfokozó szituációkban a személyek milyen mértékben mutatnak erőteljes érzelem- és viselkedésmintát (state).

Módszertani szempontból további hiányosság, hogy az általunk alkalmazott demográfiai kérdőív nem tartalmazott a párkapcsolat hosszára, az elköteleződés mértékére, illetve a szexuális orientációra vonatkozó kérdést, így ezen tényezők hatásával nem számoltunk az eredmények értelmezése során. A párkapcsolat fejlődéselmélete (Bader \& Pearson, 1983) a kapcsolatot nem stabil és állandó jelenségként konstruálja, hanem azt, mint folyamatosan változó jelenséget kezeli. Annak a ténye, hogy a kutatásban résztvevő személyek aktuálisan a párkapcsolat eltérő fejlődési fázisában vannak és másféle elköteleződést mutatnak, jelentősen befolyásolhatja a kapott eredményeket. Dijkstra, Barelds és Groothof (2013) álláspontja szerint a vizsgálati személyek szexuális orientációja szintén fontos befolyásoló faktor lehet, hiszen a heteroszexuális személyek magasabb féltékenység értékeket mutatnak, mint a homoszexuális személyek. A későbbi kutatások során érdemes ezen változók hatásával is számolni. Végül, az alkalmazott kérdőívek sorában a Pszichológiai Jóllét Skálák faktorainak reliabilitás mutatói egyes esetekben nem bizonyultak megfelelőnek, így azt unidimenzionális mérőeszköznek tekintettük, ezáltal a féltékenység pszichológiai jóllét összetevőivel való kapcsolatáról nem alakult ki részletesebb kép.

Összefoglalva, jelen tanulmány célja a Bringle (2013) által kidolgozott Önbevallásos Féltékenység Skála részletes pszichometriai vizsgálata volt. A kutatás legfőbb ereje annak nagy elemszámú, széles életkori spektrumot felölelő normatív mintán történő adatfelvételében és részletes pszichometriai elemzésében rejlik. A tárgyalt limitációk figyelembevétele mellett a diszpozícionális féltékenység mérésére szolgáló első magyar nyelven hozzáférhető, rövid, könnyen felvehetó mérőeszközt adjuk közre jelen tanulmányban. Az Önbevallásos Féltékenység Skála mind a négy skálája jó belső konzisztenciát mutat, a konfirmatív faktoranalízis eredménye pedig az elfo- 
gadhatóhoz közelító illeszkedést jelez. A korábbi empirikus kutatásoknak megfelelően a féltékenység és az önértékelés, illetve a depresszió vonatkozásában kapott gyenge negatív együttjárás, valamint a féltékenység vonásszorongással való mérsékelt erôsségú pozitív korrelációja igazolja az Önbevallásos Féltékenység Skála konstruktum validitását. A nemi különbség, a részletes életkori csoportok elemzése és a párkapcsolati státusz kapcsán kapott eredményeink is alátámasztják a kérdőív kostruktum validitását.

Az Önbevallásos Féltékenység Skála magyar nyelvú változata megfelelő kiinduló pontja lehet szélsőségesen magas féltékenységgel jellemezhető személyek populációszintú azonosításához, amely például a párkapcsolati erőszak elkövetése szempontjából fontos oki tényező (Belus és mtsai, 2014). Mindemellett az Önbevallásos Féltékenység Skála klinikai - elsősorban paranoid személyiségzavarban, kényszeres és kapcsolódó zavarokban szenvedő, illetve szerhasználó - mintán végzett további empirikus kutatások számára is adekvát mérőeszközt nyújt.

\section{Irodalom}

Bader, E., \& Pearson, P. (1983). The developmental stages of couplehood. Transactional Analysis Journal, 13(1), 28-32.

Dijkstra, P., Barelds, D.P., \& Groothof, H.A. (2013). Jealousy in response to online and offline infidelity: The role of sex and sexual orientation. Scandinavian Journal of Psychology, 54(4), 328-336.

Bech, P., Gudex, C., \& Johansen, K.S. (1996). The WHO (Ten) Well-Being Index: Validation in diabetes. Psychotherapy and Psychosomatics, 65(4), 183-190.

Belus, J.M., Wanklyn, S.G., Iverson, K.M., Pukay-Martin, N.D., Langhinrichsen-Rohling, J., \& Monson, C. (2014). Do anger and jealousy mediate the relationship between adult attachment styles and intimate violence perpetration? Partner Abuse, 5(4), 388-406.

Bendixen, M., Kennair, L.E.O., \& Buss, D.M. (2015). Jealousy: Evidence of strong sex differences using both forced choice and continuous measure paradigms. Personality and Individual Differences, 86, 212-216.

Bringle, R.G. (1991). Psychosocial aspects of jealousy: A transactional model. In P. Salovey (Eds.), The psychology of jealousy and envy (103-131). New York: The Guilford Press

Bringle, R.G. (2013). Self-Report Jealousy Scale-Revised. In N. Fredman, \& R. Sherman (Eds.), Handbook of measurements for marriage and family therapy (116-124). Abingdon: Routledge Press

Bringle, R.G., Roach, S., Adler, C., \& Evenback, S. (1979). Measuring the intensity of jealous reactions. Journal Supplement and Abstract Service: Catalog of Selected Documents, 9, 23-24.

Buss, D.M., Larsen, R.J., Westen, D., \& Semmelroth, J. (1992). Sex differences in jealousy: evolution, physiology and psychology . Psychological Science, 3(4) 251-255.

Buunk, B.P. (1997). Personality, birth order and attachment styles as related to various types of jealousy. Personality and Individual Differences, 23, 997-1006.

Cohen, J. (1988). Statistical power analysis for the behavioral sciences ( $2^{\text {nd }}$ ed.). Hillsdale: Erlbaum 
Costa, A.L., Sophia, E.C., Sanches, C., Tavares, H., \& Zilberman, M.L. (2015). Pathological jealousy: Romantic relationship characteristics, emotional and personality aspects, and social adjustment. Journal of Affective Disorders, 174, 38-44.

Demetrovics, Zs. (2007). Drog, család, személyiség: A különböző típusú drogok használatának személyiségpszichológiai és családi háttere. Budapest: L'Harmattan Kiadó

Elphinston, R.A., Feeney, J.A., \& Noller, P. (2011). Measuring romantic jealousy: Validation of the multidimensional jealousy scale in Australian samples. Australian Journal of Psychology, 63(4), 243-251.

Freud, S., \& Strachey, J. (1922). Some neurotic mechanisms in jealousy, paranoia and homosexuality. In N. Bruke (Eds.), Gender and envy (221-232). New York: Routledge

Green, M.C., \& Sabini, J. (2006). Gender, socioeconomic status, age, and jealousy: Emotional responses to infidelity in a national sample. Emotion, 6(2), 330-334.

Haraszti, L. (1994). A féltékenység pszichodinamikai elméletei. Szenvedélybetegségek, 2(5), 349-361.

Hendrick, S.S., Dicke, A., \& Hendrick, C. (1998). The relationship assessment scale. Journal of Social and Personal Relationships, 15(1), 137-142.

Hunyady, O. (1999). A szerelmi féltékenység és az irigység relációja. Alkalmazott Pszichológia, 1(4), 35-42.

Klein, M. (1957). Envy \& gratitude. Psyche, 11(5), 241-255.

Lennarz, H.K., Lichtwarck-Aschoff, A., Finkenauer, C., \& Granic, I. (2017). Jealousy in adolescents' daily lives: How does it relate to interpersonal context and well-being?. Journal of Adolescence, 54, 18-31.

Lima, A.B., Köhler, C.A., Stubbs, B., Quevedo, J., Hyphantis, T.N., Koyanagi, A., et al. (2017). An exploratory study of the heterogeneity of the jealousy phenomenon and its associations with affective temperaments and psychopathological dimensions in a large Brazilian sample. Journal of Affective Disorders, 212, 10-16.

Martos, T., Sallay, V., Szabó, T., Lakatos, C., \& Tóth-Vajna, R. (2014). A Kapcsolati Elégedettség Skála magyar változatának (RAS-H) pszichometriai jellemzői. Mentálhigiéné és Pszichoszomatika, 15(3), 245-258.

Mathes, E.W., \& Severa, N. (1981). Jealousy, romantic love, and liking: Theoretical considerations and preliminary scale development. Psychological Reports, 49(1), 23-31.

McAndrew, F.T., \& Shah, S.S. (2013). Sex differences in jealousy over Facebook activity. Computers in Human Behavior, 29(6), 2603-2606.

Muise, A., Christofides, E., \& Desmarais, S. (2009). More information than you ever wanted: Does Facebook bring out the green-eyed monster of jealousy?. CyberPsychology and Behavior, 12(4), 441-444.

Oláh, A. (2012). A megküzdés szívárványszínei: a stresszkezeléstől a boldogság növeléséig. In M. Fülöp, \& É. Szabó (Szerk.), A pszichológia mint társadalomtudomány - A 70 éves Hunyady György tiszteletére (507-522). Budapest: ELTE Eötvös Kiadó

Parrott, W.G., \& Smith, R.H. (1993). Distinguishing the experiences of envy and jealousy. Journal of Personality and Social Psychology, 64(6), 906-920.

Perczel-Forintos, D., Ajtay, Gy., Barna, Cs., Kiss, Zs., \& Komlósi, S. (2018). Kérdôivek, becslőskálák a klinikai pszichológiában (57-58). Budapest: Semmelweis Kiadó és Multimédia Stúdió

Peretti, P.O., \& Pedowski, B.C. (1997). Influence of jealousy on male and female college daters. Journal of Social Behavior and Personality, 25(2), 155-160.

Pfeiffer, S.M., \& Wong, P.T. (1989). Multidimensional jealousy. Journal of Social and Personal Relationships, 6(2), 181-196. 
Radloff, L.S. (1991). The use of the Center for Epidemiologic Studies Depression Scale in adolescents and young adults. Journal of Youth and Adolescence, 20(2), 149-166.

Rosenberg, M. (1965). Society and the Adolescent Self-image. New Jersey, Princeton: University Press

Rózsa S., Nagybányai O., \& Oláh A. (2006). A pszichológiai mérés alapjai. Budapest: Bölcsész Konzorcium

Rőmer, G., \& Fekete, N. (2014). A facebook okozta párkapcsolati féltékenység az önértékelés, a szorongás és a kötődési stílusok tükrében. Alkalmazott Pszichológia, 14(1), 149-161.

Ryff, C.D., \& Keyes, C.L.M. (1995). The structure of psychological well-being revisited. Journal of Personality and Social Psychology, 69(4), 719-727.

Sagarin, B.J., Martin, A.L., Coutinho, S.A., Edlund, J.E., Patel, L., Skowronski, J.J., et al. (2012). Sex differences in jealousy: A meta- analytic examination. Evolution and Human Behavior, 33(6), 595-614.

Sallay, V., Martos, T., Földvári, M., Szabó, T., \& Ittzés, A. (2014). A Rosenberg Önértékelés Skála (RSES-H): alternatív fordítás, strukturális invariancia és validitás. Mentálhigiéné és Pszichoszomatika, 15(3), 259-275.

Sipos, K., Sipos, M., \& Spielberger, C.D. (1994): A State-Trait Anxiety Inventory (STAI) magyar változata. In F. Mérei, \& F. Szakács (Szerk.), Pszichodiagnosztikai vademecum I/2. (123-148). Budapest: Nemzeti Tankönyvkiadó

Stravogiannis, A.L.D.C., Kim, H.S., Sophia, E.C., Sanches, C., Zilberman, M.L., \& Tavares, H. (2018). Pathological jealousy and pathological love: Apples to apples or apples to oranges?. Psychiatry Research, 259, 562-570.

Susánszky, É., Konkolÿ Thege, B., Stauder, A., \& Kopp, M. (2006). A WHO Jól-lét Kérdőív rövidített (WBI-5) magyar változatának validálása a Hungarostudy 2002 országos lakossági egészségfelmérés alapján. Mentálhigiéné és Pszichoszomatika, 7(3), 247-255.

Tagler, M.J., \& Gentry, R.H. (2011). Gender, jealousy, and attachment: A (more) thorough examination across measures and samples. Journal of Research in Personality, 45(6), 697701.

Tošić Radev, M., \& Hedrih, V. (2017) Psychometric properties of the Multidimensional Jealousy Scale (MJS) on a Serbian sample. Psihologija, 50(4), 521-534.

Vagg, R.L.P., \& Spielberger, G.J.C. (1983). State-Trait Anxiety Inventory for adults sampler set: Manual, test, scoring key. California: Mind Garden

Voracek, M. (2001). Marital status as a candidate moderator variable of male-female differences in sexual jealousy: The need for representative population samples. Psychological Reports, 88(2), 553-566.

White, G.L., \& Mullen, P.E. (1989). Jealousy: Theory, research, and clinical strategies. New York: Guilford Press

\section{Köszönetnyilvánítás}

A közlemény megírása, illetve a kapcsolódó kutatómunka anyagi támogatásban részesült az Új Nemzeti Kiválóság Program ÚNKP-18-2-I-PPKE-82 számú pályázata által.

\section{Szerzói munkamegosztás}

B.C.: a kutatási módszertan kidolgozása, a vizsgálat lefolytatása, szakirodalom-kutatás, statisztikai elemzések, a kézirat első változatának kialakítása és megszövegezése. H.R.: a kutatási módszertan szupervíziója, a statisztikai adatok értelmezése, a kézirat véglegesítése. 


\section{Nyilatkozat érdekütközésról}

A szerzők ezúton kijelentik, hogy esetükben nem állnak fenn érdekütközések.

\section{FÜGGELÉK \\ Önbevallásos Féltékenység Skála}

A következőkben különböző szituációkat fog olvasni, amik esetleg Önnel is megtörténtek, vagy megtörténhetnek. Kérem értékelje őket az alapján, hogy hogyan érezné magát, ha átélné ezeket a helyzeteket! A válaszadás során 5 lehetőségből választhat az alapján, hogy az adott esemény mennyire zaklatja fel Önt érzelmileg. Kérem minden állításra válaszoljon!

\begin{tabular}{|l|c|c|c|c|c|}
\cline { 2 - 5 } \multicolumn{1}{l|}{} & $\begin{array}{c}\text { Egyálta- } \\
\text { lán nem } \\
\text { zaklat fel }\end{array}$ & $\begin{array}{c}\text { Enyhén } \\
\text { felzaklat }\end{array}$ & $\begin{array}{c}\text { Fel- } \\
\text { zaklat }\end{array}$ & $\begin{array}{c}\text { Nagyon } \\
\text { fel- } \\
\text { zaklat }\end{array}$ & $\begin{array}{c}\text { Extrém } \\
\text { módon } \\
\text { felzaklat }\end{array}$ \\
\hline $\begin{array}{l}\text { 1. A párod kifejezi az igényét arra, } \\
\text { hogy mindketten alakítsatok ki } \\
\text { másokkal is romantikus kapcsolatot. }\end{array}$ & 0 & 1 & 2 & 3 & 4 \\
\hline $\begin{array}{l}\text { 2. A párod egyre több idejét tölti a } \\
\text { munkahelyén egy olyan munkatárs } \\
\text { társaságában, akit szerinted partnered } \\
\text { szexuálisan vonzónak talál. }\end{array}$ & 0 & 1 & 2 & 3 & 4 \\
\hline $\begin{array}{l}\text { 3. A párod hirtelen el szeretne menni } \\
\text { egy összejövetelre, amikor megtudja, } \\
\text { hogy ott lesz egy korábbi szerelmi } \\
\text { partnere. }\end{array}$ & 0 & 1 & 2 & 3 & 4 \\
\hline $\begin{array}{l}\text { 4. Egy összejövetelen a párod rajtad } \\
\text { kívül mást is átkarol. }\end{array}$ & 0 & 1 & 2 & 3 & 4 \\
\hline $\begin{array}{l}\text { 5. Többször is rajtakapod a párod, } \\
\text { hogy valaki mást figyel. }\end{array}$ & 0 & 1 & 2 & 3 & 4 \\
\hline $\begin{array}{l}\text { 6. A párod egyre több idót tölt olyan } \\
\text { házon kívüli tevékenységekkel, illetve } \\
\text { hobbikkal, amikben te nem veszel } \\
\text { részt. }\end{array}$ & 0 & 1 & 2 & 3 & 4 \\
\hline $\begin{array}{l}\text { 7. Egy összejövetelen a párod } \\
\text { megpuszil valakit, akit nem ismersz. }\end{array}$ & 0 & 1 & 2 & 3 & 4 \\
\hline $\begin{array}{l}\text { 8. A fönököd, akivel régóta jó } \\
\text { munkakapcsolatban állsz, nagyobb } \\
\text { érdeklődést tanúsít egy másik } \\
\text { munkatársad iránt. }\end{array}$ & 0 & 1 & 2 & 3 & 4 \\
\hline $\begin{array}{l}\text { 9. A párod több éjszaka nélküled } \\
\text { megy el szórakozóhelyre. }\end{array}$ & 0 & 1 & 2 & 3 & 4 \\
\hline
\end{tabular}




\begin{tabular}{|c|c|c|c|c|c|}
\hline & $\begin{array}{l}\text { Egyálta- } \\
\text { lán nem } \\
\text { zaklat fel }\end{array}$ & $\begin{array}{l}\text { Enyhén } \\
\text { felzaklat }\end{array}$ & $\begin{array}{c}\text { Fel- } \\
\text { zaklat }\end{array}$ & $\begin{array}{l}\text { Nagyon } \\
\text { fel- } \\
\text { zaklat }\end{array}$ & $\begin{array}{l}\text { Extrém } \\
\text { módon } \\
\text { felzaklat }\end{array}$ \\
\hline $\begin{array}{l}\text { 10. A párodat előléptetik, az új } \\
\text { pozíciójával rengeteg utazás, üzleti } \\
\text { ebéd, összejövetel jár, melyek közül a } \\
\text { legtöbbre nem tarthatsz vele. }\end{array}$ & 0 & 1 & 2 & 3 & 4 \\
\hline $\begin{array}{l}\text { 11. Egy összejövetelen a párod olyan } \\
\text { emberrel táncol, akit nem ismersz. }\end{array}$ & 0 & 1 & 2 & 3 & 4 \\
\hline $\begin{array}{l}\text { 12. Egy munkatársaddal keményen } \\
\text { dolgoztatok egy nagyon fontos } \\
\text { projekten. A fónököd mégis csak neki } \\
\text { adott érte prémiumot. }\end{array}$ & 0 & 1 & 2 & 3 & 4 \\
\hline 13. Valaki flörtöl a pároddal. & 0 & 1 & 2 & 3 & 4 \\
\hline $\begin{array}{l}\text { 14. Egy összejövetelen a párod } \\
\text { többször is megpuszil valakit, akit te } \\
\text { nem ismersz. }\end{array}$ & 0 & 1 & 2 & 3 & 4 \\
\hline $\begin{array}{l}\text { 15. A párod szexuális kapcsolatot } \\
\text { létesít valaki mással. }\end{array}$ & 0 & 1 & 2 & 3 & 4 \\
\hline $\begin{array}{l}\text { 16. A testvéred több szabadságot kap, } \\
\text { mint te, például tovább maradhat } \\
\text { fent, vezetheti a családi autót, stb. }\end{array}$ & 0 & 1 & 2 & 3 & 4 \\
\hline $\begin{array}{l}\text { 17. A párod megemlíti, hogy egy } \\
\text { másik személyt nagyon vonzónak } \\
\text { talál. }\end{array}$ & 0 & 1 & 2 & 3 & 4 \\
\hline $\begin{array}{l}\text { 18. Egy baráti összejövetelen a párod } \\
\text { alig beszélget veled, viszont a } \\
\text { többiekkel élénk társalgást folytat. }\end{array}$ & 0 & 1 & 2 & 3 & 4 \\
\hline $\begin{array}{l}\text { 19. A nagyszüleid családi látogatást } \\
\text { tesznek, és minden figyelmüket a } \\
\text { testvérednek/testvéreidnek szentelik. }\end{array}$ & 0 & 1 & 2 & 3 & 4 \\
\hline 20. A párod valaki mással flörtöl. & 0 & 1 & 2 & 3 & 4 \\
\hline $\begin{array}{l}\text { 21. A testvéred/testvéreid több } \\
\text { szeretetet és/vagy figyelmet kapnak a } \\
\text { szüleidtől. }\end{array}$ & 0 & 1 & 2 & 3 & 4 \\
\hline $\begin{array}{l}\text { 22. Rájössz, hogy a párodnak } \\
\text { viszonya van egy munkatársával. }\end{array}$ & 0 & 1 & 2 & 3 & 4 \\
\hline $\begin{array}{l}\text { 23. Az az ember, aki több évig az } \\
\text { asszisztensed volt, most úgy dönt, } \\
\text { hogy másnál szeretne ugyanebben a } \\
\text { pozícióban dolgozni. }\end{array}$ & 0 & 1 & 2 & 3 & 4 \\
\hline
\end{tabular}




\begin{tabular}{|l|c|c|c|c|c|}
\cline { 2 - 6 } \multicolumn{1}{c|}{} & $\begin{array}{c}\text { Egyálta- } \\
\text { lán nem } \\
\text { zaklat fel }\end{array}$ & $\begin{array}{c}\text { Enyhén } \\
\text { felzaklat }\end{array}$ & $\begin{array}{c}\text { Fel- } \\
\text { zaklat }\end{array}$ & $\begin{array}{c}\text { Nagyon } \\
\text { fel- } \\
\text { zaklat }\end{array}$ & $\begin{array}{c}\text { Extrém } \\
\text { módon } \\
\text { felzaklat }\end{array}$ \\
\hline $\begin{array}{l}\text { 24. A csoport, amihez tartozol, kihagy } \\
\text { a terveiböl, a közös tevékenységeiből } \\
\text { stb. }\end{array}$ & 0 & 1 & 2 & 3 & 4 \\
\hline $\begin{array}{l}\text { 25. A legjobb barátod hirtelen egy } \\
\text { másik személy iránt érdeklődik, } \\
\text { szívesen tölt együtt vele időt. }\end{array}$ & 0 & 1 & 2 & 3 & 4 \\
\hline
\end{tabular}

\title{
Skálaképzés:
}

A kérdőív nem tartalmaz fordított tételeket. A skálaképzés a hozzájuk tartozó tételek összeadásával történik.

Párkapcsolati gyanakvás: 2., 3., 4., 5., 6., 7., 9., 10., 11., 13., 14., 17., 18. és 20. tétel

Reális párkapcsolati féltékenység: 1., 15. és 22. tétel

Társas féltékenység: 8., 12., 23., 24. és 25 tétel

Testvérféltékenység: 16., 19. és 21. tétel

\section{The psychometric characteristics of the Hungarian version of the Self-Report Jealousy Scale}

\author{
BUDINSZKI, CINTIA - HARGITAI, RITA
}

Background: Lots of unimodal and complex questionnaires can be identified, that measures jealousy. One of these is the 25 item Self-Report Jealousy Scale. Aim: The Hungarian version of the Self-Report Jealousy Scale has not been available yet, therefore the primary aim of the study was to establish it and examine the psychometric properties of this questionnaire. Method: Detailed psychometric analysis of the Self-Report Jealousy Scale was conducted on a large normative sample of healthy adults $(N=1384$, mean age 27.3 [SD $=9.10$ ] years) in a cross-sectional, questionnaire-based research design. Measures: Self-Report Jealousy Scale (SRJS), State Trait Anxiety Inventory (STAI-T), Center for Epidemiologic Studies Depression Scale (CES-D), Psychological Wellbeing Scale (PWB), WHO Well-being Index (WBI 5), Relationship Assessment Scale (RAS-H), and Rosenberg Self-Esteem Scale (RSES-H). Results: The exploratory factor analysis revealed four factors (Relationship suspiciousness, Reasonable relationship jealousy, Social jealousy, Sibling jealousy) which taken together, explained $62 \%$ of the total variance. In contrast with the original threestructure model, the confirmatory factor analysis verifies the four-factore model. The reliability analysis indicated good internal consistency for the instrument. The sex differences, the detailed analysis of age groups, and the differences based on marital status support the construct-validity. Furthermore, as in the previous researches, the low negative 
correlation between jealousy and self-esteem $(r=-0.28, p<0.001)$, and the low positive association between jealousy and depressive symptoms $(r=0.30, p<0.001)$, and the moderate relationship with anxiety $(r=0.37, p<0.001)$ support the Self-Report Jealousy Scale construct-validity. Conclusions: The results indicate that the Hungarian version of the Self-Report Jealousy Scale (SRJS-H) is a reliable and valid measure for assessing the level of dispositional jealousy that gives an adequate instrument for further population-based and clinical studies.

Keywords: jealousy, Self-Report Jealousy Scale, reliability, validity, self-esteem, anxiety, depression

A cikk a Creative Commons Attribution 4.0 International License (https:/ / creativecommons.org/ licenses/by/4.0/) feltételei szerint publikált Open Access közlemény, melynek szellemében a cikk bármilyen médiumban szabadon felhasználható, megosztható és újraközölhető, feltéve, hogy az eredeti szerző és a közlés helye, illetve a CC License linkje és az esetlegesen végrehajtott módosítások feltüntetésre kerülnek. (SID_1) 